\title{
Acinetobacter Strain KUO11TH, a Unique Organism Related to Acinetobacter pittii and Isolated from the Skin Mucus of Healthy Bighead Catfish and Its Efficacy Against Several Fish Pathogens
}

\author{
Anurak Bunnoy ${ }^{1}$ (D), Uthairat Na-Nakorn ${ }^{2}$, Pattanapon Kayansamruaj ${ }^{1}$ \\ and Prapansak Srisapoome ${ }^{1, *(D)}$ \\ 1 Laboratory of Aquatic Animal Health Management, Department of Aquaculture, Faculty of Fisheries, \\ Kasetsart University, 50 Paholayothin Rd, Ladyao, Chatuchak, Bangkok 10900, Thailand; \\ anurak.bunnoy@gmail.com (A.B.); pattanapon.k@ku.ac.th (P.K.) \\ 2 Laboratory of Aquatic Animal Genetics, Department of Aquaculture, Faculty of Fisheries, Kasetsart \\ University, 50 Paholayothin Rd, Ladyao, Chatuchak, Bangkok 10900, Thailand; ffisurn@ku.ac.th \\ * Correspondence: ffispssp@ku.ac.th
}

Received: 19 September 2019; Accepted: 8 November 2019; Published: 10 November 2019

\begin{abstract}
The bacterial strain KU011TH was isolated from the skin mucus of healthy bighead catfish. The strain is a Gram-negative coccobacillus that is nonmotile, aerobic, catalase positive, oxidase negative, and nonhemolytic. Sequence analyses of the housekeeping genes $16 S r R N A$, gyrB and rpoB indicate that this strain is a new member of the Acb complex of the genus Acinetobacter and is closely related to Acinetobacter pittii and Acinetobacter lactucae. In addition, the genome relatedness-associated ANIb ( $<95-96 \%)$ and in silico DDH ( $<70 \%)$ values clearly supported the new member of the genus Acinetobacter and the Acb complex. The genome of the strain KU011TH was approximately $3.79 \mathrm{Mbp}$ in size, comprising 3619 predicted genes, and the DNA G+C content was $38.56 \mathrm{~mol} \%$. The major cellular fatty acids were $\mathrm{C} 18: 1 \omega 9 \mathrm{c}, \mathrm{C} 16: 0, \mathrm{C} 16: 1, \mathrm{C} 20: 2, \mathrm{C} 18: 2 \omega 6 \mathrm{c}$ and C18:1 $\omega 9 \mathrm{t}$. The whole-genome sequences and phenotypic, phylogenetic, and chemotaxonomic data clearly support the classification of the strain KU011TH as a new member in the genus Acinetobacter which is closest to A. pittii. Additionally, the new bacterial strain exhibited strong activity against a broad range of freshwater fish pathogens in vitro.
\end{abstract}

Keywords: Acinetobacter; $16 \mathrm{~S}$ rRNA; gyrB; rpoB; genome sequence; ANI; in silico DDH; Clarias microcephalus; probiotics; antagonists; Acb complex

\section{Introduction}

The genus Acinetobacter, belonging to the family Moraxellaceae, was first established by Brisou \& Prevot [1] with the type species Acinetobacter lwoffii. This genus currently includes 61 published valid species names, including four pairs of synonyms (https://apps.szu.cz/anemec/Classification. pdf, 26 August 2019). Bacteria of the genus Acinetobacter are characteristically Gram-negative, nonmotile, catalase-positive, oxidase-negative, coccobacillus aerobes that survive under a wide range of environmental conditions. Representatives of the genus Acinetobacter have DNA G+C levels ranging from 34.9 to $47.0 \mathrm{~mol} \%$ [2], and C18:1 $\omega 9 \mathrm{c}$ and C16:0 are the major cellular fatty acids [3]. Despite being described as nonmotile bacteria, Acinetobacter spp. possess different forms of motility, such as twitching movement due to the pilus features on their cell membrane [4]. 
The genus Acinetobacter is a large and diverse group of biochemically, physiologically and naturally multitalented bacteria. Seven Acinetobacter species with valid published names, namely, A. beijerinckii, A. gyllenbergii, A. haemolyticus, A. junii, A. parvus, A. tjernbergiae and A. venetianus, belong to hemolytic clades. These bacteria have hemolytic characteristics and can lyse mammalian red blood cells [5-8]. Moreover, the Acinetobacter calcoaceticus-Acinetobacter baumannii (Acb) complex is also an important group of bacteria in the genus Acinetobacter; these bacteria were isolated from a wide range of environmental habitats and are symptomatically associated with human health. These bacteria currently include six different valid published species, namely, A. calcoaceticus, A. baumannii, A. pittii, A. nosocomialis, A. seifertii and A. lactucae (a later heterotypic synonym of A.dijkshoorniae) $[9,10]$. The major characteristics of the Acb complex are genetically and physiologically highly similar to each other and difficult to distinguish at the species level by standard methods [11]. However, these species differ in their epidemiology, antibiotic resistance and pathogenicity [12]. Some members of the Acb complex, especially A. baumannii, are typically mentioned among Acb complex members associated with opportunistic pathogens in humans with the emergence of antibiotic resistance $[11,13,14]$. In addition, A. pittii, A. nosocomialis, A. seifertii and A. lactucae are ubiquitous and widespread and are occasionally associated with emerging important nosocomial pathogens involved in hospital-acquired infections $[9,10,15]$. During the last decade, some Acb complex and non-Acb complex members have been reported as septicemia pathogens that cause mass mortality in aquatic animals such as fishes, including mandarin fish (Siniperca chuatsi) [13], channel catfish (Ietalurus punetaus) [14], hybrid Prussian carp (Carassais auratus gibebio) [16], and loach (Misgurnus anguillicaudatus) [15].

Although most of the members of the genus Acinetobacter have been isolated from human clinical specimens and reported as important opportunistic pathogens, the characterization of new members from nonhuman environments and of their benefits to the environment and animals has never been performed. Recently, many novel species of the genus Acinetobacter have been thoroughly characterized after being isolated from natural sources, such as honey bees, horses, cotton, rice, bark from Populus $\mathrm{x}$ euramericana cankers, vegetables, activated sludge, soil, river water and other environmental sources worldwide [10,17-24].

To our knowledge, catfish farming in Thailand has substantially increased in recent decades. The catfish industry not only has annually helped increase the national income of Thailand but also has produced an affordable source of animal proteins for consumers in the country and around the world. The annual production of catfish is the second highest in the Thai fish aquaculture industry, after Nile tilapia (Oreochromis niloticus), with approximately 76,000 million tons produced in 2000 and a peak production of 159,314 million tons in 2004. Since 2004, the decline in Thai catfish production has averaged $5.76 \%$ annually [25]. The native bighead catfish (Clarias macrocephalus Günther, 1864) is an important catfish species in the aquaculture industry in Thailand. Because of its unique meat composition, bighead catfish has been used as a brood stock for producing hybrid catfish (C. macrocephalus $\times$ C. gariepinus). Unfortunately, this species is slow growing, produces limited numbers of fry, is susceptible to infectious diseases and is sensitive to various environmental conditions [26]. Specifically, this species is prone to outbreaks of diseases caused by pathogenic bacteria, especially Aeromonas hydrophila and Flavobacterium columnare, which has become a major problem contributing to the declining catfish production in Thailand. Traditionally, chemicals and antibiotics have been widely applied to treat diseases in cultured catfish. However, the adverse effects of these substances have been a cause for concern for many years since excessive usage of antibiotics and chemicals can lead to the generation of drug-resistant bacteria and to food and environmental contamination [27]. Alternatively, beneficial and effective microorganisms known as "probiotics" have been introduced into a number of aquatic animal species in the aquaculture industry to control infectious bacterial diseases and enhance growth and immune responses [28]. However, a promising bacterial species originally cultured from Thai catfish has never been described and assessed for use in the catfish industry. 
Here, we describe the characteristics of a new bacterial strain of the genus Acinetobacter, strain KU011TH. The bacterial strain KU011TH was isolated from the skin mucus of healthy bighead catfish in catfish farms in Pathum Thani Province, Thailand. The complete taxonomic characterization of the bacterial strain supported the classification of the bacterial strain KU011TH as a new member of the genus Acinetobacter and the Acb complex, and the name Acinetobacter sp. KU011TH is proposed for this strain with the type strain is KU011TH. Furthermore, the obtained data on this novel bacterial strain are necessary for further study of its function and antagonistic efficacy against various fish pathogens that cause harmful diseases in bighead catfish (C. macrocephalus) and other fish species. The wide-ranging inhibitory effects of the novel bacterial strain warrant further research to identify effective strategies for its use in disease prevention. The new preliminary research findings on this novel bacterial strain could be expanded upon for the development of a potential probiotic approach to help sustain the catfish aquaculture industry.

\section{Materials and Methods}

\subsection{Bacterial Isolation and Cultivation}

A colony of the bacterial strain KU011TH was isolated from the skin mucus of bighead catfish. The skin mucus was serially diluted $10^{-1}$ to $10^{-4}$ in physiological saline $(0.85 \% \mathrm{NaCl})$, placed on plate count agar (PCA, containing $0.5 \%$ tryptone, $0.3 \%$ yeast extract, $1.0 \%$ dextrose/glucose and $1.5 \%$ agar; HiMedia Laboratories) and cultured at $32{ }^{\circ} \mathrm{C}$ for $24 \mathrm{~h}$. After incubation, a distinct circular colony with a cream color, an entire edge and a convex shape was subcultured on standard nutrient broth (NB, containing $0.5 \%$ tryptone, $0.3 \%$ yeast extract and $1.0 \%$ dextrose/glucose) for $18-24 \mathrm{~h}$. Bacterial pellets were separated by centrifugation at $3000 \times g$ for $5 \mathrm{~min}$, suspended in glycerol $(20 \% \mathrm{v} / \mathrm{v})$ and then preserved at $-80^{\circ} \mathrm{C}$. Microscopic examinations of colony and cell morphology were performed to confirm that no contamination by other groups of bacteria occurred. The strain KU011TH was routinely grown on PCA and in NB medium at $\mathrm{pH} 7.3$ and $32{ }^{\circ} \mathrm{C}$ for $18-24 \mathrm{~h}$ for all phenotypic tests.

This study was carried out in accordance with the principle of the Basel Declaration and the recommendations of the Guide for the Care and Use of Laboratory Animals of the Ethical Committee of Kasetsart University, Thailand, with the approval number ACKU61-FIS-004, approval date: 9 September 2018.

\subsection{Bacterial Cell Morphology Analysis}

Gram staining of bacterial cells grown on PCA or PCA with $1.5 \%(w / v) \mathrm{NaCl}$ was performed using light microscopy (Olympus, MA, USA) under 1000 $\times$ magnification as described in [29]. Bacterial cell size and morphology were analyzed via scanning electron microscopy (SEM) (SU8020, Hitachi High-Technologies, Tokyo, Japan). Briefly, bacterial colonies were grown on PCA plates at $32{ }^{\circ} \mathrm{C}$ for $24 \mathrm{~h}$, and thereafter, a single colony was fixed with SEM fixative overnight. The colony samples were dehydrated through an ascending series of ethanol concentrations and then subjected to supercritical drying in a critical point dryer. The samples were sputter coated with gold and inspected by SEM.

\subsection{DNA Extraction, PCR Amplification and DNA Sequencing}

To identify the strain at the species level, the genomic DNA of the bacterial strain KU011TH was obtained using the QIAamp DNA Mini Kit (QIAamp, CA, USA) following the manufacturer's instructions. DNA was amplified to obtain almost full-length nucleotide sequences of the 16S $r R N A$ gene using the bacterial universal primers $27 f$ (5'-AGAGTTTGATCMTGGCTCAG-3') and 1492r (5'-TACGGYTACCTTGTTACGACTT-3') [9,30]. Additionally, parts of the RNA polymerase beta-subunit $(r p o B)$ and DNA gyrase subunit B (gyrB) genes were also amplified with the rpoB-696f (5'-TAYCGYAAAGAYTTGAAAGAAG-3'), rpoB-1598r (5'-CGBGCRTGCATTTGTCRT-3'), gyrBf (5'-CAGGAAACAGCTATGACCAYGSNGGNGGN AARTTYRA-3') and $g y r B r\left(5^{\prime}\right.$-TGTAAAACGACGGCCAGTGCNGGRTCYTTYTCYTG RCA-3') primers, which have been previously described [31,32], to verify the genotypic similarities between the novel species and the other 
members of the genus. The PCRs were performed using Phusion high-fidelity DNA polymerase with proofreading activity (Thermo Fisher Scientific, Waltham, MA, USA) according to the manufacturer's instructions. The PCR was initiated with a predenaturation step at $95^{\circ} \mathrm{C}$ for $5 \mathrm{~min}$, which was followed by 30 cycles of $95^{\circ} \mathrm{C}$ for $30 \mathrm{~s}, 55^{\circ} \mathrm{C}$ for $30 \mathrm{~s}$, and $72{ }^{\circ} \mathrm{C}$ for $2 \mathrm{~min}$ and then finished with postextension at $72{ }^{\circ} \mathrm{C}$ for $10 \mathrm{~min}$. The PCR products were purified and cloned into the CloneJET1.2/blunt vector (Thermo Fisher Scientific, MA, USA), and the constructs were sequenced by the Macrogen sequencing service (Macrogen Inc., Seoul, Korea) using the pJET1.2 forward and reverse sequencing primers.

\subsection{Phylogenetic Analysis}

The sequences of the $16 S$ rRNA, gyrB and rpoB genes were BLASTed (https://blast.ncbi.nlm.nih. gov/Blast.cgi) against the latest release of the GenBank database. Similarity calculations for the obtained sequences were performed using MATGAT version 2.0 software [33]. Additionally, the DNA sequences were aligned with those of related Acinetobacter species using ClustalW [34]. Phylogenetic trees were constructed using Molecular Evolutionary Genetics Analysis (MEGA) software, version 7.0 (Proprietary freeware, Japan) [35], with neighbor-joining (NJ) [36] algorithms with a bootstrap of 1000 replications.

\subsection{Genome Sequencing, Assembly and Annotation}

The quality of the extracted DNA was determined using QubitTM fluorometric quantitation (Thermo Fisher Scientific, USA). Preparation of the DNA sequencing library was carried out using Nextera XT kits (Illumina, San Diego, CA, USA), and whole-genome sequencing was performed subsequently using paired-end runs on an Illumina HiSeq platform with a 251-bp read length. Library preparation and whole-genome sequencing were performed by a service provider (Novogene, Singapore). Raw data were then trimmed to filter out low-quality (Q score $<30$ ) and contaminating reads prior to de novo assembly using the A5-miseq pipeline, version MCS 2.3 [37]. The quality of the derived assemblies was determined using the QUAST program [38]. Only contigs with lengths $>1000 \mathrm{bp}$ were used for further genome annotation using the MicroScope web-based service (http://www.genoscope.cns.fr/agc/microscope) [39].

\subsection{Genome Sequencing Analysis, ANI, in silico DDH Calculations and Phylogeny}

Bacterial genomic relatedness was investigated by different algorithms for genome-to-genome comparison. The average nucleotide identity (ANI) values were calculated based on BLAST (ANIb) using the web service JSpeciesWS online server (http://jspecies.ribohost.com/jspeciesws/) [40]. For in silico DNA-DNA hybridization (DDH) analysis, the results were obtained from the genome-to-genome distance calculator (GGDC) web service using formula 2 (identities/HSP length) (http://ggdc.dsmz. de) [41]. The recommended species cut-offs were lower than $95-96 \%$ for ANIb and $70.0 \%$ for in silico DDH values [42,43]. The genome BLAST distance phylogeny (GBDP) of the bacterial strain KU011TH, closely related Acb complex species and non-Acb complex species in the genus Acinetobacter was examined using the type strain genome server (TYGS) [44].

\subsection{DNA G+C Content Analysis}

The $\mathrm{G}+\mathrm{C}$ content of the bacterial strain KU011TH was automatically obtained from genome calculations using the ANI calculator and MicroScope web platform [38,39].

\subsection{GenBank/EMBL/DDBJ Accession Numbers}

The nucleotide sequences of the bacterial strain KU011TH have been deposited at DDBJ/EMBL/GenBank under the accession numbers MG372049 for the 165 rRNA gene, MG950236 for the $g y r B$ gene, and MG950238 for the $r p o B$ gene. The annotated whole-genome shotgun project has been deposited at DDBJ/ENA/GenBank under the accession number PSSN00000000. The version described in this paper is version PSSN01000000.1. 


\subsection{Phenotypic and Chemotaxonomic Analyses}

Cytochrome c oxidase activity was determined as previously described [45]. Catalase activity was analyzed with $3 \%$ hydrogen peroxide solution, and the production of oxygen bubbles indicated a positive result. Hemolytic activity was tested on Muller-Hinton (MH) agar containing sterile $10 \%(v / v)$ whole sheep blood. Cell motility and oxidative and fermentative activities were analyzed using Hugh and Leifson's agar (oxidative-fermentative (OF) basal medium; Merck, Germany) supplemented with $10 \%(w / v)$ D-glucose. Growth tests at different temperatures $\left(4,25,30,37,41\right.$ and $\left.45^{\circ} \mathrm{C}\right), \mathrm{pH}$ values (4.0-10.0 at intervals of $1.0 \mathrm{pH}$ unit) and $\mathrm{NaCl}$ concentrations $(0-10 \% w / v)$ were performed in $10.0 \mathrm{~mL}$ of MH broth (HiMedia Laboratories). The growth of the bacterium was measured by determining the absorbance at $600 \mathrm{~nm}$ and using standard plate counting techniques at 24-hr intervals for 7 days. Tests for the utilization of other carbon sources were performed using API $50 \mathrm{CHB} / \mathrm{E}$ test kits (bioMérieux, France). API 20NE (bioMérieux, France) and API 20E test kits (bioMérieux, France) were also used to determine the enzyme activities of the strain according to the manufacturer's instructions. To confirm the API phenotypic results, hydrolysis of starch, casein and urea was investigated with standard microbiological assays by incubating the strain on starch agar (HiMedia Laboratories), skim milk (HiMedia Laboratories) and urea agar base (HiMedia Laboratories) supplemented with sterile $40 \%$ urea solution, respectively. Lipase activity was tested on tributyrin agar (HiMedia Laboratories) [46], and a clear zone around a colony was interpreted as a positive result. All phenotypic tests were performed in triplicate.

\subsection{Cellular Fatty Acid Analysis}

Bacterial cells were cultivated on $\mathrm{MH}$ agar at $32{ }^{\circ} \mathrm{C}$ for $24 \mathrm{~h}$. Cellular fatty acids were obtained by saponification, methylation and extraction according to version 6.2 of the Sherlock Microbial Identification (MIDI) System by following the instructions for the system [47]. The cellular fatty acid profiles were analyzed by separation of fatty acid methyl esters by a gas chromatography-based method. Peaks were automatically integrated and calculated using Sherlock MIDI, version 6.2 (MIDI, Inc., Newark, DE, USA) [47,48].

\subsection{Identification of Antibiotic Resistance Genes}

The output genome assembly was used to search for similar antibiotic resistance genes in the Comprehensive Antibiotic Resistance Database (CARD) (https://card.mcmaster.ca/home) [49] using BLAST+ [50]. The results were reported according to only the best hits of the genes from the database.

\subsection{Antibiotic Susceptibility Test}

An antibacterial susceptibility test of the bacterial strain KU011TH was performed using the disk diffusion method [51,52]. The cultured bacterial suspension of $2.0 \times 10^{8} \mathrm{CFU} / \mathrm{mL}$ was grown and prepared as described above and then swabbed on $\mathrm{MH}$ agar plates. Commercial paper antibiotic disks with fixed concentrations were placed on the inoculated agar surface. Eighteen antibiotics obtained from Thermo Scientific ${ }^{\mathrm{TM}}$ were used in this study, namely, ampicillin (AMP10), amoxicillin (AML10), ciprofloxacin (CIP5), chloramphenicol (C30), cephalothin (KF30), doxycycline (DO30), erythromycin (E15), enrofloxacin (FNR5), neomycin (N30), novobiocin (NV5), oxytetracycline (OT30), polymyxin B (PB300), spectinomycin (SH25), sulfamethoxazole (SXT25), sulfamethoxazole (RL25), cefoperazone (SCF105), tetracycline (TE30) and trimethoprim (W5). The plates were incubated for $18-24 \mathrm{~h}$ at $37^{\circ} \mathrm{C}$ prior to determination of the results. After incubation, the clear zones of growth inhibition around each of the antibiotic disks were measured in millimeters. The diameter of the clear zone is related to the susceptibility of the isolate, which was interpreted using the criteria published by the Clinical and Laboratory Standards Institute (CLSI) [52]. The results were qualitatively classified into three categories of susceptibility: susceptible, intermediate, and resistant. The test was performed in three replications. 


\subsection{Antagonism Against Pathogenic Bacteria}

The antagonistic activity of the bacterial strain KU011TH against pathogenic bacteria was evaluated using both agar dot-spot and quantitative real-time PCR (qPCR) assays. Ten strains that are pathogenic to freshwater and marine aquatic animals obtained from the Laboratory of Aquatic Animal Health Management, Department of Aquaculture, Faculty of Fisheries, Kasetsart University, Thailand, were used to evaluate antagonistic activity. Six strains of freshwater fish pathogens, namely, A. hydrophila, F. columnare, Flectobacillus roseus, Streptococcus agalactiae, Staphylococcus warneri, and Edwardsiella tarda, and four strains of marine fish pathogens, namely, Vibrio alginolyticus, Vibrio harveyi, Vibrio parahaemolyticus AHPND and Vibrio vulnificus, were tested.

Using methods previously described in [53], an agar dot-spot assay was conducted on PCA and PCA with $1.5 \%(w / v) ~ N a C l$ for freshwater and marine fish pathogens, respectively. The individual strains of isolate KU011TH and pathogenic bacteria were first inoculated on PCA or PCA with 1.5\% $(w / v) \mathrm{NaCl}$ plates at $32{ }^{\circ} \mathrm{C}$ for $18 \mathrm{~h}$. After incubation, the cells of the pathogens were collected and resuspended in phosphate-buffered saline (PBS, pH 7.4). A concentration of approximately $1.0 \times 10^{6} \mathrm{CFU} / \mathrm{mL}$ was used for this experiment. The bacterial suspension was immediately swabbed on prepared PCA or PCA with $1.5 \% \mathrm{NaCl}$ plates. Then, the strain KU011TH on PCA plates was dot-spotted on the plates that had previously been swabbed with the respective pathogens. After $18 \mathrm{~h}$ of incubation at $32{ }^{\circ} \mathrm{C}$, the diameters of the clear zones of growth inhibition were measured in millimeters. The test was performed thrice on each plate with three replications.

\subsection{Quantitative Analysis of Bacterial Coculture Assay Results}

Quantification of the activity of the bacterial strain KU011TH against ten pathogenic bacteria was conducted by coculturing the bacteria and using qPCR assays. The alteration of the cell morphology of the cocultured bacteria was visualized by light microscopy (Olympus, MA, USA) under 1000× magnification. A single colony of a freshwater or marine pathogenic bacterium was either inoculated in $30 \mathrm{~mL}$ of standard NB (containing $0.5 \%$ tryptone, $0.3 \%$ yeast extract and $1 \%$ dextrose/glucose) or NB medium with $1.5 \% \mathrm{NaCl}$ at $32{ }^{\circ} \mathrm{C}$ for $18 \mathrm{~h}$. The strain $\mathrm{KU} 011 \mathrm{TH}$ was also inoculated in $\mathrm{NB}$ and NB with $1.5 \% \mathrm{NaCl}$ medium for coculture with freshwater and marine pathogenic bacteria. After incubation, bacterial inoculum was collected, purified by centrifugation at $2500 \times \mathrm{g}$ for $5 \mathrm{~min}$ and resuspended in PBS ( $\mathrm{pH} 7.4$ ) to attain a final concentration of $1.0 \times 10^{5} \mathrm{CFU} / \mathrm{mL}$. All bacterial strains were further monitored for growth on both single-culture and cocultured plates at $24 \mathrm{~h}$. One milliliter of each pathogenic bacterial suspension $\left(1.0 \times 10^{5} \mathrm{CFU} / \mathrm{mL}\right)$ was cocultured with $1.0 \mathrm{~mL}$ of the bacterial strain KU011TH in a total culture volume of $50 \mathrm{~mL}$ of $\mathrm{NB}$ or $\mathrm{NB}$ with $1.5 \% \mathrm{NaCl}$ medium at $32{ }^{\circ} \mathrm{C}$ for $24 \mathrm{~h}$. The ratio of the cocultured bacteria was 1:1. The estimated starting number of each bacterial strain was $2.0 \times 10^{3} \mathrm{CFU} / \mathrm{mL}$ (total starting concentration of $4.0 \times 10^{3} \mathrm{CFU} / \mathrm{mL}$ of each coculture). For the control of each bacterial strain, $1.0 \mathrm{~mL}$ of each bacterial suspension was grown without strain KU011TH in a total culture volume of $50 \mathrm{~mL}$ of $\mathrm{NB}$ or NB with $1.5 \% \mathrm{NaCl}$ medium at $32{ }^{\circ} \mathrm{C}$ for $24 \mathrm{~h}$, and the growth was measured as a single culture.

At $24 \mathrm{~h}$ of cultivation, $1.0 \mathrm{~mL}$ aliquots from all cocultures and single cultures (control) of each test were collected to extract genomic DNA for quantifying DNA copy number and determining the proportion of cultured bacteria using a qPCR assay. Bacterial genomic DNA was obtained using the QIAamp DNA Mini Kit (QIAamp, CA, USA) following the manufacturer's instructions. The primers for the qPCR assay were designed to measure primer specificity and efficiency for individual strains (Table 1). 
Table 1. Specific primers for qPCR-based bacterial quantification in single and coculture assays of the bacterial strain KU011TH and pathogenic bacteria.

\begin{tabular}{|c|c|c|c|c|}
\hline Bacterial Strains & Primer Names & Nucleotide Sequence $\left(5^{\prime}->3^{\prime}\right)$ & $\begin{array}{l}\text { Amplicon } \\
\text { Size (bp) }\end{array}$ & $\begin{array}{l}\text { Accession } \\
\text { Number }\end{array}$ \\
\hline Acinetobacter sp. KU011TH & $\begin{array}{l}\text { KU011TH_F } \\
\text { KU011TH_R }\end{array}$ & $\begin{array}{l}\text { GGCGTGCGTATTGTTTTACGTGAT } \\
\text { CAATACCGTTTTCTGTATCTGCGG }\end{array}$ & 154 & MG950236 \\
\hline Aeromonas hydrophila & $\begin{array}{l}\text { Aeromonas_F } \\
\text { Aeromonas_R }\end{array}$ & $\begin{array}{l}\text { CAAGGCTGATATCTCCTATCCCTATG } \\
\text { GCCACTCAGGGTCAGGTCAT }\end{array}$ & 66 & KU196733 \\
\hline Flavobacterium columnare & $\begin{array}{l}\text { Flavobac_F } \\
\text { Flavobac_R }\end{array}$ & $\begin{array}{l}\text { CCTGTACCTAATTGGGGAAAAGAGG } \\
\text { GCGGTTATGGCCTTGTTTATCATAGA }\end{array}$ & 113 & СР018912 \\
\hline Flectobacillus roseus & $\begin{array}{l}\text { Flectoba_F } \\
\text { Flectoba_R }\end{array}$ & $\begin{array}{l}\text { AGGGTAGCTACCAGGCAACTGG } \\
\text { ATCCCGTTCTTGACGCGGAAC }\end{array}$ & 202 & MG322214 \\
\hline Streptococcus agalactiae & $\begin{array}{l}\text { Strepto_F } \\
\text { Strepto_R }\end{array}$ & $\begin{array}{l}\text { GGAAACCTGCCATTTGCGTCT } \\
\text { AATCTATTTCTAGATCGTGGAAT }\end{array}$ & 190 & СР033822 \\
\hline Staphylococcus warneri & $\begin{array}{l}\text { Staphylo_F } \\
\text { Staphylo_F }\end{array}$ & $\begin{array}{l}\text { TGTAGCTAACTTAGATAGTGTTCCTTCT } \\
\text { CCGCCACCGTTATTTCTT }\end{array}$ & 62 & СР033098 \\
\hline Edwardsiella tarda & $\begin{array}{l}\text { Edward_F } \\
\text { Edward_R }\end{array}$ & $\begin{array}{l}\text { CAGTGATAAAAAGGGGTGGA } \\
\text { CTACACAGCAACGACAACG }\end{array}$ & 114 & СР023706 \\
\hline $\begin{array}{c}\text { Vibrio alginolyticus } \\
\text { Vibrio harveyi } \\
\text { Vibrio parahaemolyticus } \\
\text { Vibrio parahaemolyticus AHPND } \\
\text { Vibrio vulnificus }\end{array}$ & $\begin{array}{l}\text { Vibrio_F } \\
\text { Vibrio_R }\end{array}$ & $\begin{array}{l}\text { GGCGTAAAGCGCATGCAGGT } \\
\text { GAAATTCTACCCCCCTCTACAG }\end{array}$ & 120 & $\begin{array}{l}\text { GQ455007* } \\
\text { GQ455008* } \\
\text { HQ123986* } \\
\text { NR117907* }\end{array}$ \\
\hline
\end{tabular}

* The designed primers were based on the 16S rRNA genes of various Vibrio spp. in the NCBI database under accession numbers GQ455007, GQ455008, HQ123986, and NR117907 to evaluate all Vibrio bacterial strains.

A qPCR assay was performed with Brilliant III Ultra-Fast SYBR ${ }^{\circledR}$ Green (Agilent, CA, USA) in Mx3005P QPCR Systems (Agilent, Santa Clara, CA, USA). The qPCRs were optimized in $20 \mu \mathrm{L}$ reaction volumes containing $10 \mu \mathrm{L}$ of $2 \times$ SYBR Green QPCR Master Mix with $0.5 \mathrm{mM}$ primer. qPCR cycling conditions included an initial cycle of $95^{\circ} \mathrm{C}$ for $5 \mathrm{~min} ; 40$ cycles of $95^{\circ} \mathrm{C}$ for $30 \mathrm{~s}, 55^{\circ} \mathrm{C}$ for $30 \mathrm{~s}$, and $72^{\circ} \mathrm{C}$ for $90 \mathrm{~s}$; followed by a final extension at $72^{\circ} \mathrm{C}$ for $10 \mathrm{~min}$. The specificity of the primer set was validated against the eleven reference strains. Using the above optimized real-time PCR amplification conditions, a standard curve for quantification of all bacterial strains was prepared using 10-fold DNA serial dilution from $10^{2}$ to $10^{10}$ copy numbers $/ \mathrm{mL}$. The threshold cycle $\left(C^{T}\right)$ was measured for each qPCR. The calculated $C^{T}$ values of the samples were then plotted against the numbers of microorganisms compared to the control (single culture). The resulting values (DNA copy numbers) were calculated from the standard equation for each bacterial strain. All tests and qPCRs were performed in triplicate.

The results for the numbers of bacteria are presented as the mean \pm standard deviation. Student's $t$-test was used to analyze the data. A $p$ value less than 0.05 was considered statistically significant.

\section{Results and Discussion}

The bacterial strain KU011TH was isolated from the skin mucus of healthy bighead catfish (C. macrocephalus Günther, 1864) in Pathum Thani Province, Thailand, on 20 August 2016. Cells from the bacterial strain KU011TH were Gram-negative, non-spore-forming coccobacilli. The cells had various sizes, ranging from 0.8 to 1.5 microns. Pilus structures were found on the cell membranes of the bacterial strain, as shown in Figure 1. 

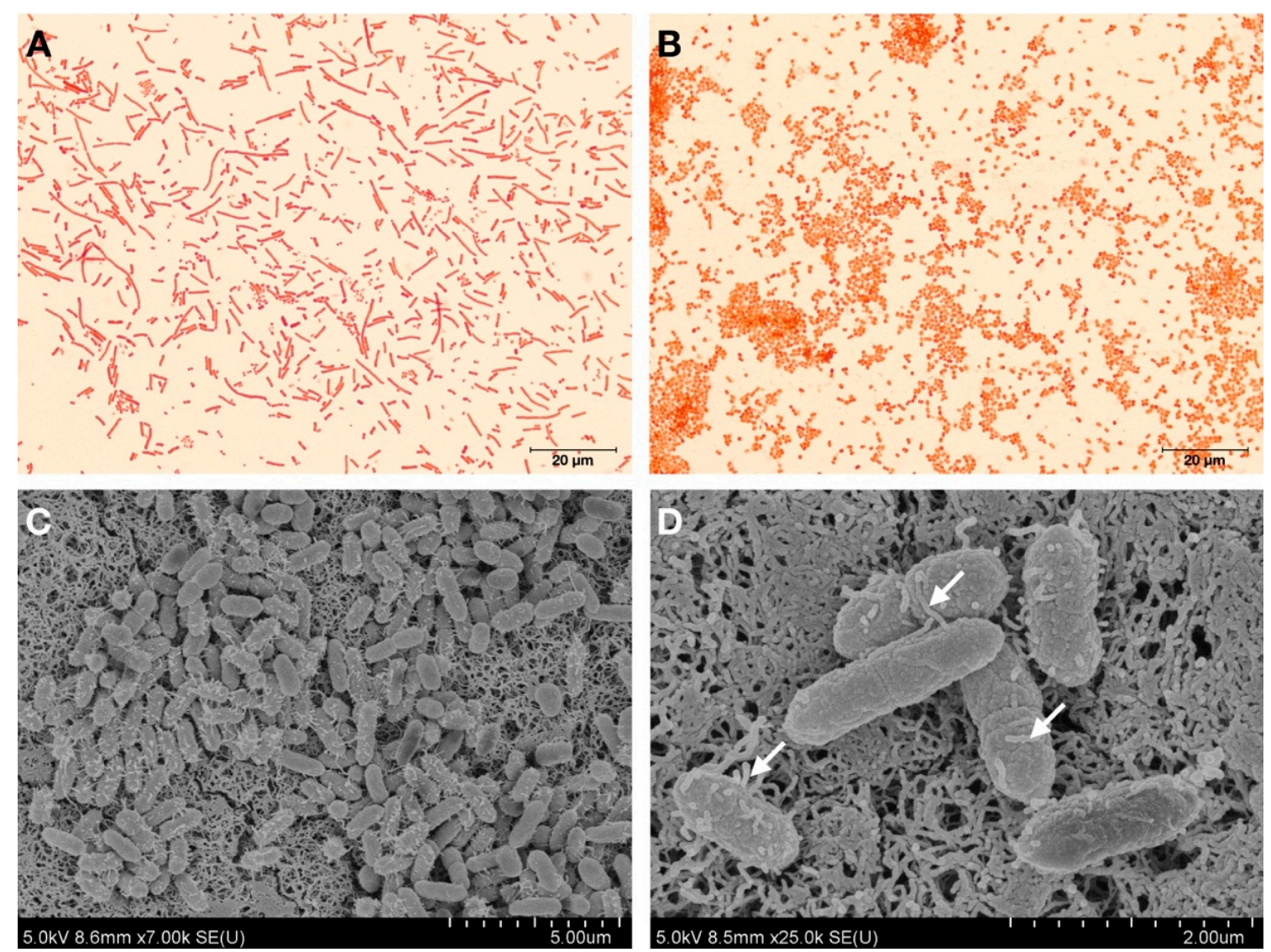

Figure 1. Gram staining and cell morphology observed by light microscopy $(100 \times)$ of the bacterial strain KU011TH grown on different media: PCA (A) and PCA with 1.5\% $\mathrm{NaCl}$ (B). Scanning electron micrographs of the bacterial strain $\mathrm{KU} 011 \mathrm{TH}(\mathbf{C}, \mathbf{D})$. Arrows indicate the presence of pili on the bacterial cell wall.

A comparison of the sequences of the housekeeping genes $16 S$ rRNA, gyrB and rpoB showed that the bacterial strain KU011TH clustered with the members of the Acb complex of the genus Acinetobacter. The $16 S$ rRNA sequences of the bacterial strain shared high similarity, ranging from 98.0 to $99.9 \%$, with the sequences from the bacterial strains in the Acb complex. Furthermore, the similarities of the $g y r B$ and $r p o B$ genes ranged from 87.6 to $97.6 \%$ and 87.6 to $98.7 \%$, respectively. Based on sequence analysis of three housekeeping genes, the species most closely related to the bacterial strain KU011TH among the species in the Acb complex were A. pittii, A. lactucae, A. calcoaceticus, A. nosocomialis, A. seifertii and A. baumannii. Gene sequence similarities between the bacterial strain KU011TH and the most closely related strains in the Acb complex and in the genus Acinetobacter are shown in Table 2. 
Table 2. Sequence similarity and origin of the bacterial strain KU011TH and the most closely related type strain in the genus Acinetobacter.

\begin{tabular}{|c|c|c|c|c|}
\hline \multirow{2}{*}{ Bacterial Strain } & \multicolumn{3}{|c|}{$\begin{array}{c}\text { Sequence Similarity with Strain } \\
\text { KU011TH (\%) }\end{array}$} & \multirow{2}{*}{ Origin of Bacterial Isolate } \\
\hline & $\begin{array}{l}\text { 16S rRNA } \\
\text { Gene }\end{array}$ & $\begin{array}{l}\text { gyrB } \\
\text { Gene }\end{array}$ & $\begin{array}{l}\text { rpoB } \\
\text { Gene }\end{array}$ & \\
\hline \multicolumn{5}{|l|}{ Acb complex } \\
\hline A. lactucae NRRL B-41902 T & 99.9 & 91.2 & 96.7 & Iceberg lettuce, water \\
\hline A. pittii $\mathrm{LMG} 1035^{\mathrm{T}}$ & 99.8 & 97.6 & 98.7 & Human, soil, water \\
\hline A. calcoaceticus DSM $30006^{\mathrm{T}}$ & 99.5 & 90.4 & 93.9 & Human, soil, water \\
\hline A. nosocomialis NIPH2119 & 99.2 & 89.1 & 93.1 & Human \\
\hline A. seifertii $\mathrm{NIPH} 973^{\mathrm{T}}$ & 99.1 & NR & 87.6 & Clinical specimen \\
\hline $\begin{array}{l}\text { A. baumannii ATCC } 19606^{\mathrm{T}} \\
\text { Non-Acb complex }\end{array}$ & 98.0 & 87.6 & 93.6 & Clinical specimen \\
\hline A. dispersus ANC $4105^{\mathrm{T}}$ & 98.0 & 78.7 & 85.1 & Clinical specimen \\
\hline A. proteolyticus NIPH $809^{\mathrm{T}}$ & 98.0 & 76.4 & 84.6 & Clinical specimen \\
\hline A. apis $\mathrm{HYN} 18^{\mathrm{T}}$ & 97.6 & NR & 78.2 & Tract of a honey bee \\
\hline A. albensis ANC $4874^{\mathrm{T}}$ & 97.5 & 72.1 & 81.9 & Natural soil and water \\
\hline A. vivianii NIPH $2168^{\mathrm{T}}$ & 97.4 & 76.4 & 84.6 & Clinical specimen \\
\hline A. courvalinii ANC $3623^{\mathrm{T}}$ & 97.1 & 76.6 & 83.3 & Conjunctiva (agama lizard) \\
\hline A. nectaris SAP $763^{\mathrm{T}}$ & 97.5 & 72.4 & 77.6 & Flower (floral nectar) \\
\hline A. bohemicus ANC $3994^{\mathrm{T}}$ & 97.5 & 54.0 & 80.3 & Natural soil and water \\
\hline A. boissieri SAP $284^{\mathrm{T}}$ & 96.7 & 69.3 & 82.9 & Flower (floral nectar) \\
\hline A. guangdongensis $1 \mathrm{NM}-4^{\mathrm{T}}$ & 96.6 & 71.7 & 78.7 & Abandoned lead-zinc ore \\
\hline A. modestus NIPH $236^{\mathrm{T}}$ & 96.8 & 78.3 & 84.1 & Urine / clinical specimen \\
\hline A. hemolyticus DSM6962 T & 96.5 & 75.2 & 81.0 & Clinical specimen \\
\hline A. pragensis ANC $4149^{\mathrm{T}}$ & 96.5 & 68.6 & 84.1 & Natural soil and water \\
\hline A. puyangensis $\mathrm{BQ} 4-1^{\mathrm{T}}$ & 96.7 & 65.2 & 73.1 & $\begin{array}{c}\text { Bark of Populus } \times \text { euramericana } \\
\text { canker }\end{array}$ \\
\hline
\end{tabular}

Percent sequence similarity of $16 S$ RNA, gyrB and rpoB genes determined using MATGAT version 2.0 open-source freeware (Department of Biology and Molecular Biology, Montclair State University, New Jersey, USA) [33]. NR, not reported.

The phylogenetic tree of the $16 S$ rRNA gene sequence from the bacterial strain KU011TH and other strains in the Acb complex and non-Acb complex of the genus Acinetobacter was constructed and is shown in Figure 2. The $16 S r R N A$ gene phylogram showed that this strain was a member of the Acb complex and clearly separated from the most closely related bacterial strains in the Acb complex, especially A. lactucae (99.9\% of $16 S$ rRNA sequence similarity), A. pittii (99.8\% of $16 \mathrm{~S} r R N A$ sequence similarity) and $A$. calcoaceticus ( $99.5 \%$ of $16 S$ rRNA sequence similarity). In addition, the phylograms demonstrated that the bacterial strain KU011TH was within the same clade as the Acb complex without A. baumannii, as shown in Figure 2. Furthermore, the $16 S r R N A$ phylogram clearly shows that the bacterial strain KU011TH and several closely related strains are genotypically distinct from the valid published strains in the Acb complex and in the genus Acinetobacter. 


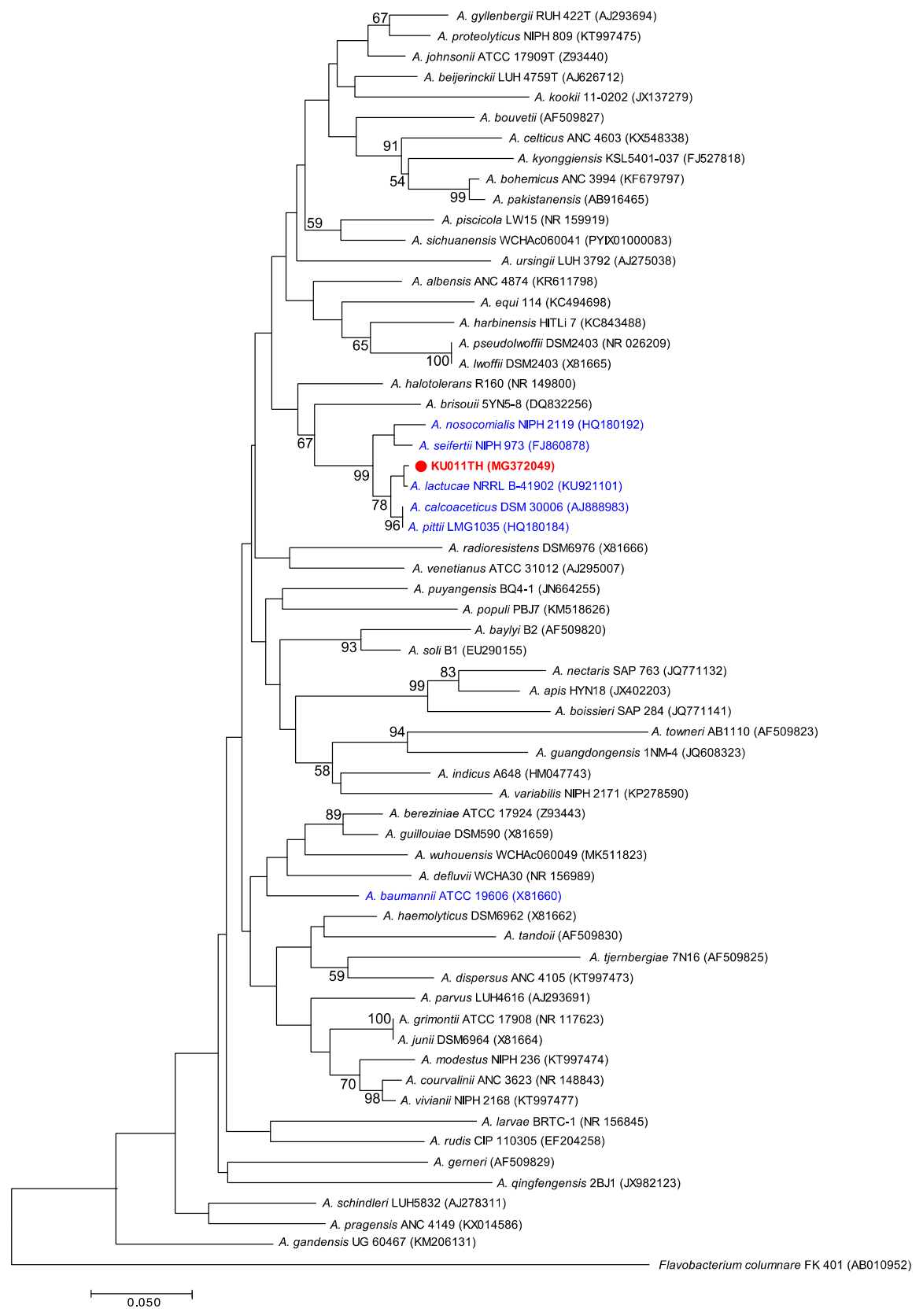

Figure 2. Phylogenetic relationships of the bacterial strain KU011TH (red colored font) and related species in the Acb complex (blue colored font) and other species in the genus Acinetobacter based on partial $16 S$ rRNA gene sequences. Sequence alignments were optimized using ClustalW [34]. Molecular Evolutionary Genetics Analysis (MEGA) software, version 5.0, with the neighbor-joining (NJ) method was used to perform phylogenetic analysis and obtain the phylogenetic tree [36]. Bootstrap values $\geq 50 \%$ based on 1000 replications are shown at branch nodes. The $16 S$ rRNA gene sequence of F. columnare FK 401 (AB010952) was used as an outgroup. The GenBank accession number of each strain is given in parentheses.

The species status of the bacterial strain KU011TH in the Acb complex was supported by the genetic relatedness determined by the genome-wide analysis, average nucleotide identity (ANIb) values and in silico DDH values. Furthermore, the ANIb and in silico DDH values between the bacterial strain KU011TH and Acb complex were 94.0-94.6\% and 62.4-63.2\%, respectively, for A. pittii; 92.2-92.7\% and 50.1-51.3\%, respectively, for A. lactucae; $89.4-90.2 \%$ and 38.5-40.8\%, respectively, for A. calcoaceticus; $87.3-87.6 \%$ and $34.1-34.5 \%$, respectively for $A$. seifertii; $87.1-87.3 \%$ and $33.7-33.9 \%$, respectively, for 
A. baumannii; and $86.8-87.2 \%$ and $33.1-33.4 \%$, respectively, for $A$. nosocomialis (Table 3). Additionally, the calculated in silico $\mathrm{DDH}$ values were also validated by the differences in percent genomic $\mathrm{G}+\mathrm{C}$ content between distinct species, which were quite close to zero and not larger than 1.0 [44].

The genetic relatedness values for ANIb and in silico DDH proved the species status between the bacterial strain KU011TH and its closest type strain in the Acb complex; the values were considerably lower than the recommended cut-off values for species delineation (95-96\% for ANIs and $70 \%$ for in silico DDH values), confirming our conclusion that the bacterial strain KU011TH represents a novel bacterial species in the Acb complex and in the genus Acinetobacter.

Table 3. Comparison of the average nucleotide identity (ANIb) and in silico DNA-DNA hybridization $(\mathrm{DDH})$ value of the bacterial strain KU011TH and its closest species in the Acb complex.

\begin{tabular}{|c|c|c|c|c|}
\hline Bacterial Strain of the Acb Complex & $\begin{array}{l}\text { Accession } \\
\text { Number }\end{array}$ & ANIb (\%) & $\begin{array}{c}\text { In silico } \\
\text { DDH (\%) }\end{array}$ & $\begin{array}{c}\mathrm{G}+\mathrm{C} \\
\text { Difference (\%) }\end{array}$ \\
\hline Acinetobacter pittii & Range & $94.0-94.6$ & $62.4-63.2$ & $0.05-0.28$ \\
\hline A. pittii XM1570 & AMXH01000001 & 94.7 & 63.2 & 0.26 \\
\hline A. pittii ANC 3678 & APQN01000001 & 94.6 & 62.4 & 0.28 \\
\hline A. pittii DSM 25618 & BBST01000001 & 94.5 & 62.7 & 0.13 \\
\hline A. pittii NBRC 110509 & BBUA01000001 & 94.5 & 63.1 & 0.05 \\
\hline A. pittii LMG1035 & NC_016603 & 94.4 & 63.1 & 0.27 \\
\hline A. pittii CR12-42 & JQNT01000001 & 94.6 & 63.1 & 0.19 \\
\hline Acinetobacter lactucae & range & $92.2-92.7$ & $50.1-51.3$ & $0.08-0.28$ \\
\hline A. lactucae ANC 4052 & APQO01000001 & 92.2 & 50.7 & 0.29 \\
\hline A. lactucae CI78 & AVOE01000001 & 92.5 & 50.5 & 0.16 \\
\hline A. lactucae OTEC-02 & NZ_CP020015 & 92.5 & 50.5 & 0.28 \\
\hline A. lactucae ABBL098 & LLGZ01000001 & 92.4 & 50.7 & 0.27 \\
\hline A. lactucae TG29425 & RFEL01000001 & 92.7 & 51.3 & 0.09 \\
\hline A. lactucae TG41018 & RFES01000001 & 92.6 & 50.1 & 0.08 \\
\hline Acinetobacter calcoaceticus & range & $89.4-90.2$ & $38.5-40.8$ & $0.01-0.19$ \\
\hline A. calcoaceticus RUH2202 & ACPK01000001 & 89.4 & 38.7 & 0.03 \\
\hline A. calcoaceticus NIPH 13 & APOE01000001 & 89.5 & 38.9 & 0.11 \\
\hline A. calcoaceticus ANC 3680 & APQH01000001 & 89.4 & 38.9 & 0.19 \\
\hline A. calcoaceticus DSM 30006 & APQI01000001 & 89.4 & 38.6 & 0.09 \\
\hline 3.5 A. calcoaceticus ANC 3811 & APQJ01000001 & 90.2 & 40.8 & 0.01 \\
\hline 3.6 A. calcoaceticus NCTC12983 & UFSJ01000001 & 89.5 & 38.5 & 0.16 \\
\hline Acinetobacter seifertii & range & $87.3-87.6$ & $34.1-34.5$ & $0.00-0.09$ \\
\hline A. seifertii C917 & АРСТ01000001 & 87.3 & 34.1 & 0.09 \\
\hline A. seifertii NIPH 973 & APOO01000001 & 87.4 & 34.2 & 0.04 \\
\hline A. seifertii KCJK1723 & LYQI01000001 & 87.4 & 34.3 & 0.04 \\
\hline A. seifertii MI421-133 & PHFF01000001 & 87.4 & 34.5 & 0.08 \\
\hline A. seifertii KCJK7915 & QAYP01000001 & 87.6 & 34.3 & 0.01 \\
\hline A. seifertii SAb133 & SNSA01000001 & 87.6 & 34.3 & 0.00 \\
\hline Acinetobacter baumannii & range & $87.1-87.3$ & $33.7-33.9$ & $0.44-0.51$ \\
\hline A. baumannii AB030 & NZ_CP009257 & 87.1 & 33.8 & 0.48 \\
\hline A. baumannii AB030 & СР009257 & 87.1 & 33.8 & 0.48 \\
\hline A. baumannii ACICU & СР000863 & 87.3 & 33.8 & 0.47 \\
\hline A. baumannii D1279779 & СР003967 & 87.2 & 33.8 & 0.44 \\
\hline A. baumannii ZW85-1 & СР006768 & 87.3 & 33.9 & 0.51 \\
\hline A. baumannii XH386 & СР010779 & 87.1 & 33.7 & 0.51 \\
\hline Acinetobacter nosocomialis & range & $86.8-87.2$ & $33.1-33.4$ & $0.06-0.34$ \\
\hline A. nosocomialis $\mathrm{P} 020$ & APCE01000001 & 86.9 & 33.4 & 0.18 \\
\hline A. nosocomialis NBRC 110500 & ВВОТ01000001 & 86.9 & 33.3 & 0.12 \\
\hline A. nosocomialis LMG 10619 & BBSR01000001 & 87.1 & 33.1 & 0.08 \\
\hline A. nosocomialis 6411 & NZ_CP010368 & 87.2 & 33.3 & 0.18 \\
\hline A. nosocomialis ABBL058 & LLFD01000001 & 86.8 & 33.3 & 0.06 \\
\hline A. nosocomialis AB6 & PXNE01000001 & 87.0 & 33.2 & 0.34 \\
\hline
\end{tabular}

The recommended species delimitation value is lower than $95-96 \%$ for ANIb and lower than $70.0 \%$ for the in silico DDH value [42,43]. ANIb, average nucleotide identity (ANI) based on BLAST; in silico DDH, in silico DNA-DNA hybridization. 
Phylogenetic analysis based on the core genome of the bacterial strain KU011TH further indicated that the bacterial strain KU011TH belonged to the Acb complex cluster in the same subcluster as A. pittii. However, our results indicated that within the Acb complex, the bacterial strain KU011TH is genomically separated from its closely related species (A. pittii) as well as from the other non-Acb complex species of the genus Acinetobacter with valid published names. The results of the phylogenetic analysis based on the core genome of the Acb complex and non-Acb complex of the genus Acinetobacter are shown in Figure 3.
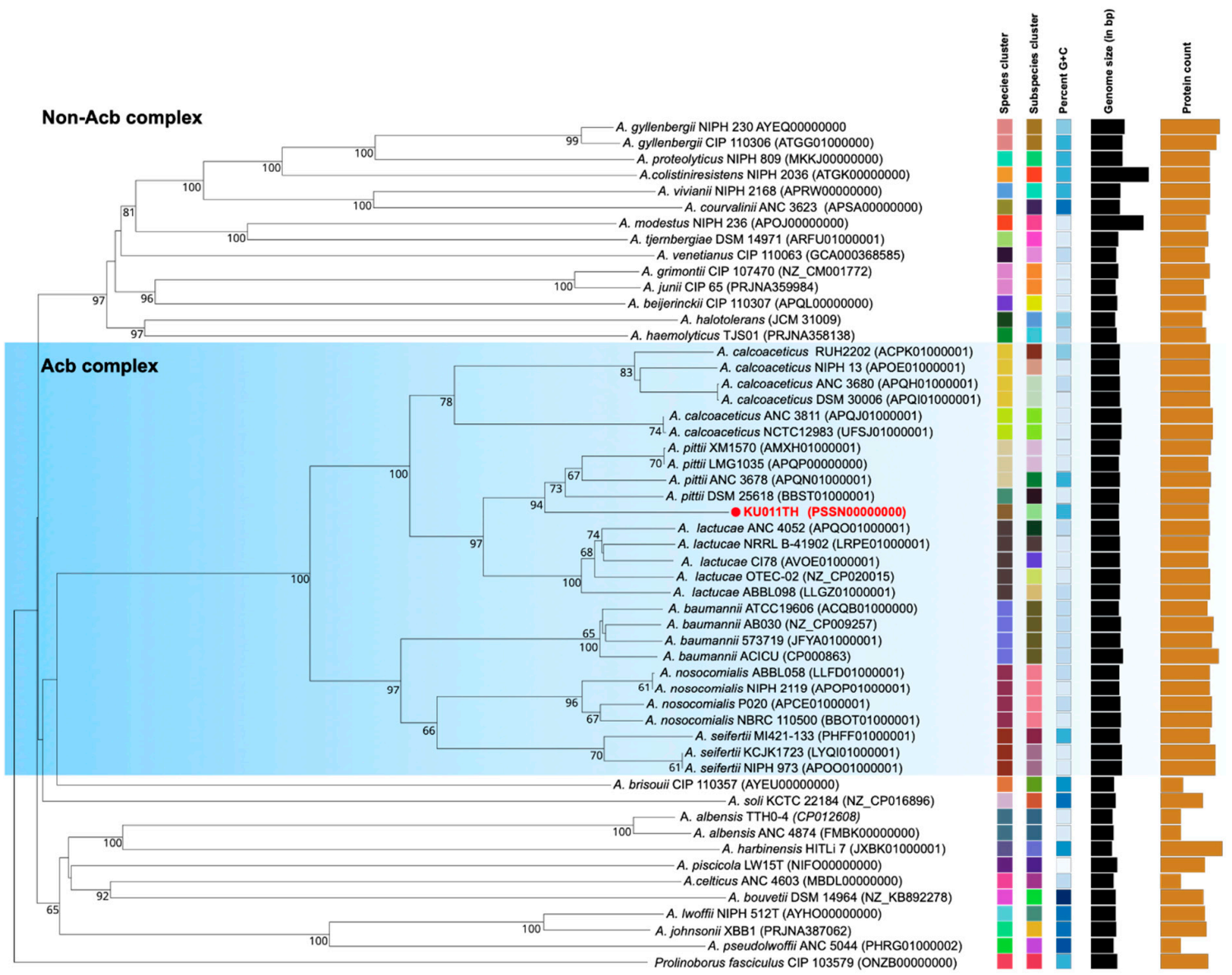

Figure 3. Genome BLAST distance phylogeny (GBDP) showing the position of the bacterial strain KU011TH (red colored font), which is closely related to the Acb complex and non-Acb complex species in the genus Acinetobacter. The type (strain) genome server (TYGS) was used to generate GBDP phylograms [44]. Bootstrap values $\geq 50 \%$ based on 1000 replications are shown at branch nodes. The genome sequences of Prolinoborus fasciculus CIP 103579 (ONZB00000000) were used as an outgroup. The GenBank genome accession number of each strain is given in parentheses.

The general genomic characteristics for bacterial strain KU011TH and closely related type strains in the Acb complex are shown in Table 4. In this study, A5-miseq generated 27 contigs from the bacterial strain KU011TH. The genome size of the novel bacterial strain was approximately $3.79 \mathrm{Mbp}$, and the N50 value was 325. The approximate coverage depth of the assemblies was $172 \times$. According to a MicroScope annotation scheme, the total number of CDSs, rRNAs and tRNAs in strain KU011TH was 3619, 8 and 63, respectively. Additionally, the genomic features and genome distribution pattern of the novel bacterial strain KU011TH are illustrated in Figure 4 and shown in Table 4, respectively. Furthermore, the $\mathrm{G}+\mathrm{C}$ content of the bacterial strain $\mathrm{KU} 011 \mathrm{TH}$ was $38.5 \mathrm{~mol} \%$, which is in the range from 34.9 to $47.0 \mathrm{~mol} \%$ reported for members of the genus Acinetobacter and close to the $\mathrm{G}+\mathrm{C}$ content of species of the Acb complex, including A. pittii (38.80 mol\%), A. lactucae (38.80 mol\%), A. calcoaceticus 
(38.70 $\mathrm{mol} \%)$, A. nosocomialis (38.70 mol\%), A. seifertii (38.60 $\mathrm{mol} \%$ ) and A. baumannii (38.90 $\mathrm{mol} \%)$ (Table 4).

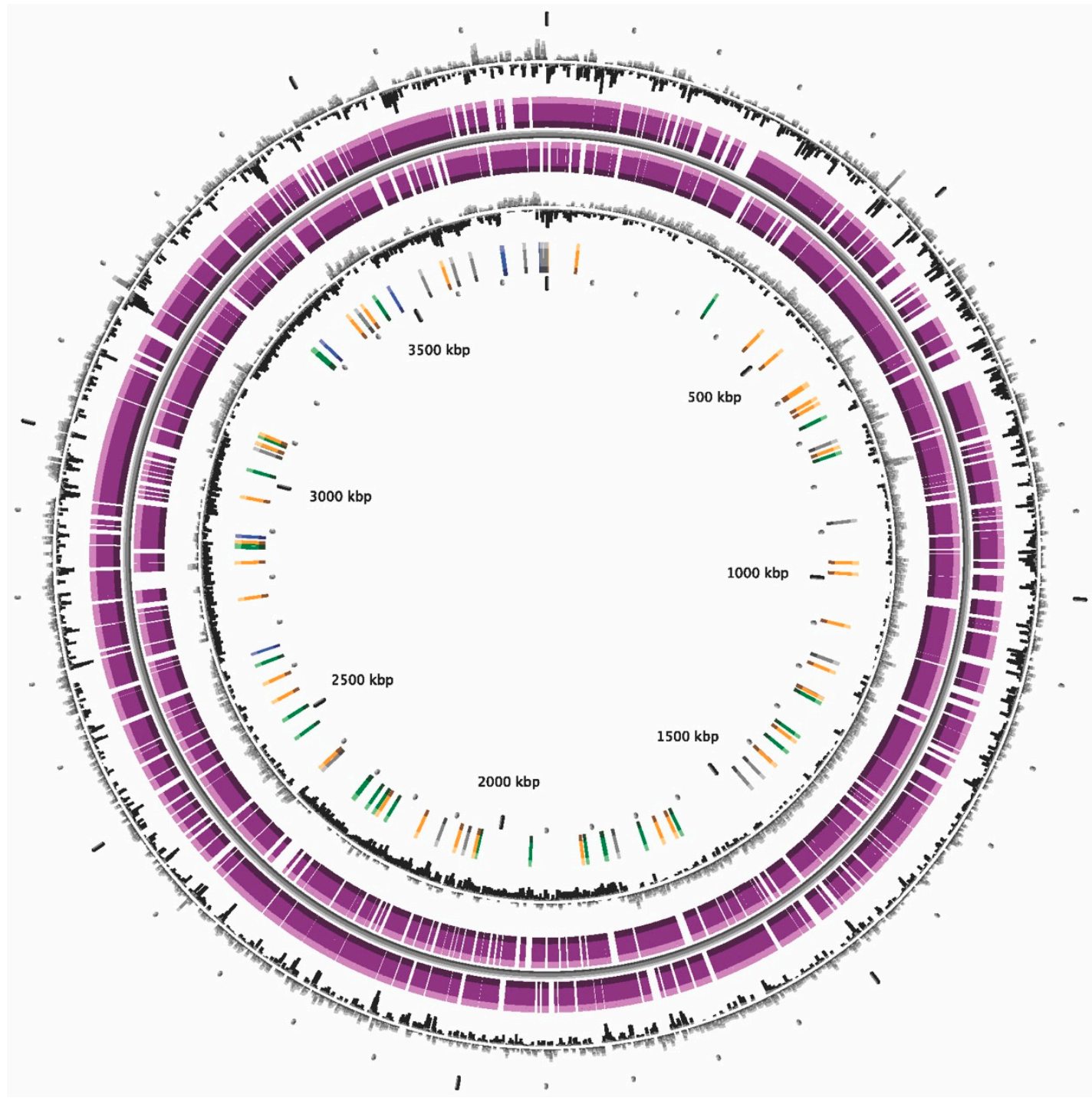

Figure 4. Graphical representation of the circular genome map of the bacterial strain KU011TH. CGView description, from the outside to the center: (1) GC percent deviation (GC window - mean GC) in a 1000-bp window. (2) Predicted CDSs transcribed in the clockwise direction. (3) Predicted CDSs transcribed in the counterclockwise direction. (4) GC skew (G+C/G-C) in a 1000-bp window. (5) rRNA (blue), tRNA (green), misc_RNA (orange), transposable elements (pink) and pseudogenes (gray).

Table 4. Genomic characteristics of the bacterial strain KU011TH (accession number PSSN00000000) and other species of the Acb complex species.

\begin{tabular}{|c|c|c|c|c|c|c|c|}
\hline \multirow[b]{2}{*}{ Bacterial Strain } & \multicolumn{7}{|c|}{ Genome Characteristics } \\
\hline & $\begin{array}{l}\text { Accession } \\
\text { Number }\end{array}$ & $\begin{array}{l}\text { Genome } \\
\text { Size }(\mathrm{Mb})\end{array}$ & $\begin{array}{c}\mathrm{G}+\mathrm{C} \\
\text { Content } \\
(\mathrm{mol} \%)\end{array}$ & Contigs & $\begin{array}{l}\text { Coding } \\
\text { Sequences } \\
\text { (CDS) }\end{array}$ & $\begin{array}{l}\text { rRNA } \\
\text { Genes }\end{array}$ & $\begin{array}{l}\text { tRNA } \\
\text { Genes }\end{array}$ \\
\hline Strain KU011TH & PSSN00000000 & 3.79 & 38.56 & 27 & 3619 & 8 & 63 \\
\hline A. pittii LMG1035 ${ }^{\mathrm{T}}$ & APQP00000000 & 3.83 & 38.80 & 33 & 3675 & 19 & 78 \\
\hline A. lactucae NRRL B- $41902^{\mathrm{T}}$ & LRPE00000000 & 3.92 & 38.60 & 94 & 3735 & 4 & 63 \\
\hline A. calcoaceticus DSM $30006^{\mathrm{T}}$ & APQI00000000 & 3.92 & 38.70 & 12 & 3808 & 18 & 75 \\
\hline A. seifertii $\mathrm{NIPH} 973^{\mathrm{T}}$ & APOO00000000 & 4.23 & 38.60 & 26 & 4180 & 13 & 70 \\
\hline A. baumannii ATCC $19606^{\mathrm{T}}$ & ACQB01000000 & 3.93 & 38.90 & 2 & 3725 & 18 & 71 \\
\hline A. nosocomialis NIPH $2119^{\mathrm{T}}$ & APOP01000001 & 3.91 & 38.70 & 19 & 3730 & 18 & 74 \\
\hline
\end{tabular}


To further evaluate the phenotypic relationship among the species of the Acb complex, metabolic and physiological tests were performed as described $[10,54]$. The strain was oxidase negative and catalase positive. Motility and hemolytic activity were not observed for the strain. However, the strain was oxidation positive and fermentation negative on OF basal medium. The strain was negative for hydrolysis of starch, casein and urea and positive for lipase activity on tributyrin agar (HiMedia Laboratories). The strain grew at temperatures ranging from 4 to $41^{\circ} \mathrm{C}$, at $\mathrm{pH}$ values from 3.0 to 10.0 , and in the presence of $0-10 \%(w / v) ~ N a C l$. Optimal strain growth was observed at $30-32{ }^{\circ} \mathrm{C}, \mathrm{pH} 7.0-8.0$ and in the presence of $1.0 \%(w / v) \mathrm{NaCl}$. The differential phenotypic characteristics of the bacterial strain KU011TH and the most closely related strains in the Acb complex of the genus Acinetobacter are shown in Table 5.

Table 5. Differential phenotypic characteristics of the bacterial strain KU011TH and the most closely related strain in the Acb complex of the genus Acinetobacter.

\begin{tabular}{|c|c|c|c|c|c|c|c|}
\hline \multirow{2}{*}{ Phenotypic Characteristics } & \multicolumn{7}{|c|}{ Bacterial Strain in the Acb Complex } \\
\hline & 1 & 2 & 3 & 4 & 5 & 6 & 7 \\
\hline Temperature range $\left({ }^{\circ} \mathrm{C}\right)$ & $4-41$ & $37-44$ & $15-44$ & $25-44$ & $25-41$ & $37-44$ & $25-41$ \\
\hline Temperature optimum $\left({ }^{\circ} \mathrm{C}\right)$ & 32 & 30 & 30 & 30 & 30 & 37 & 30 \\
\hline pH range/optimum & $3-10 / 7$ & NR & $6-9 / 7$ & NR & NR & NR & NR \\
\hline $\begin{array}{c}\mathrm{NaCl} \text { concentration range/optimum }(\% \\
w / v)\end{array}$ & $0-10 / 1$ & NR & $0-5$ & NR & NR & NR & NR \\
\hline Acidification of D-glucose & - & + & - & + & + & + & + \\
\hline Hemolysis of sheep blood & - & - & NR & - & - & - & - \\
\hline Adipate/adipic acid & - & + & NR & + & - & + & + \\
\hline Citrate (Simmons)/trisodium citrate & + & + & NR & + & + & + & + \\
\hline D-glucose & + & - & NR & - & - & - & - \\
\hline D-malate/malic acid & - & + & - & - & + & + & + \\
\hline D-ribose & + & - & NR & - & - & + & + \\
\hline DL-lactate/D-lactose & - & + & NR & + & + & + & + \\
\hline Gelatin/gelatinase & - & NR & NR & - & - & NR & NR \\
\hline L-arabinose & + & + & NR & - & - & + & + \\
\hline L-arginine & + & + & NR & + & + & + & + \\
\hline L-sorbose & - & NR & - & NR & NR & NR & NR \\
\hline
\end{tabular}

The results were either obtained in this study or have been presented previously $[10,21]$. All data were obtained from the current study using API $50 \mathrm{CH}$, API 20NE, and API 20E. Bacteria were cultured at $30^{\circ} \mathrm{C}$ except in the temperature growth tests. The strains were oxidase negative and catalase positive. Motility and hemolytic activity were not observed in the strains. All strains were negative for the hydrolysis of starch, casein, urea and gelatin. Strains: 1, strain KU011TH; 2, A. pittii [55], 3, A. lactucae [24]; 4, A. calcoaceticus [9]; 5, A. seifertii [10]; 6, A. baumannii [6]; 7, A. nosocomialis [55]. +, positive; -, negative; NR, not reported.

The predominant fatty acids in the bacterial strain KU011TH were C18:1 $\omega 9 \mathrm{c}(35.3 \%), \mathrm{C} 16: 0$ (31.2\%), C16:1 (8.5\%), C20:2 (5.2\%), C18:2w6c (3.5\%) and C18:1w9t (3.5\%). The different cellular fatty acid profiles of the bacterial strain KU011TH and the most closely related species in the Acb complex and non-Acb complex of the genus Acinetobacter are listed in Table 6. 
Table 6. Cellular fatty acid composition (\%) of the bacterial strain KU011TH and the reference type strain in the Acb complex and non-Acb complex of the genus Acinetobacter. The results were either obtained in this study or have been presented previously [10,19,54]. Strains: 1, strain KU011TH; 2, A. lactucae NRRL B-41902 T ${ }^{\mathrm{T}}$ [24]; 3, A. baumannii LMG $1041^{\mathrm{T}}$ [9]; 4, A. apis HYN18 ${ }^{\mathrm{T}}$ [56]; 5, A. indicus A $648^{\mathrm{T}}$ [57]; 6, A. radioresistens DSM 6976 ${ }^{\mathrm{T}}$ [58]; 7, A. venetianus ATCC $31012^{\mathrm{T}}$ [8]; 8, A. parvus LMG $21765^{\mathrm{T}}$ [59]; and 9, A. junii LMG $998^{\mathrm{T}}$ [6].

\begin{tabular}{cccccccccc}
\hline & \multicolumn{7}{c}{ Bacterial Strain } \\
\cline { 2 - 10 } Fatty Acid & \multicolumn{7}{c}{ Acb Complex * } & \multicolumn{7}{c}{ Non-Acb Complex } \\
\cline { 2 - 10 } & $\mathbf{1}$ & $\mathbf{2}$ & $\mathbf{3}$ & $\mathbf{4}$ & $\mathbf{5}$ & $\mathbf{6}$ & $\mathbf{7}$ & $\mathbf{8}$ & $\mathbf{9}$ \\
\hline $\mathrm{C}_{12: 0}$ & 1.8 & 5.4 & 9.7 & 8.3 & 6.4 & 11.2 & 5.1 & 5.9 & 3.8 \\
$\mathrm{C}_{14: 0}$ & 0.7 & - & 0.7 & 3.3 & 1.7 & 1.3 & 0.7 & 1.7 & 1.3 \\
$\mathrm{C}_{16: 0}$ & 31.2 & 25.2 & 17.6 & 18.0 & 10.6 & 15.6 & 18.2 & 16.8 & 16.3 \\
$\mathrm{C}_{17: 0}$ & 1.3 & 1.3 & 2.4 & $\mathrm{~L}$ & 1.5 & 1.2 & 2.4 & 0.7 & 1.7 \\
$\mathrm{C}_{18: 0}$ & 1.8 & 1.5 & 0.9 & 0.5 & 4.6 & 1.5 & 0.7 & 1.0 & 2.3 \\
$\mathrm{C}_{16: 1}$ & 8.5 & - & 6.6 & - & 4.4 & 2.4 & 0.4 & - & 0.4 \\
$\mathrm{C}_{17: 1} \omega 10$ & 0.7 & 2.0 & - & - & - & - & - & - & - \\
$\mathrm{C}_{18: 1} \omega 9 \mathrm{t}$ & 3.5 & - & - & - & - & - & - & - & - \\
$\mathrm{C}_{18: 1} \omega 9 \mathrm{c}$ & 35.4 & 36.9 & 34.9 & 6.1 & 19.6 & 25.8 & 25.2 & 38.2 & 28.1 \\
$\mathrm{C}_{18: 2} \omega 6 \mathrm{c}$ & 3.6 & - & - & - & - & 15.8 & - & - & - \\
$\mathrm{C}_{20: 2}$ & 6.0 & - & - & - & - & - & - & - & - \\
\hline
\end{tabular}

* The cellular fatty acid compositions of some valid published species of the Acb complex, including A. pittii, A. calcoaceticus, A. nosocomialis and A. seifertii, were not reported in the original publications. L, lower than $0.5 \%$; -, not detected.

The antibiotic resistance genes in strain KU011TH were analyzed by searching the CARD [49]. The obtained antibiogram of the bacterial strain KU011TH genome exhibited a number of genes that encoded resistance to several antibiotic compounds, including the $a c r A, a c r B$, alaS, amp $C$, bepE, macB, $m f d, n o l G, s m v A$ and $t u f B$ genes, and is summarized in Table 7.

Table 7. Antibiotic resistance genes identified following comparison of the genome sequence of the bacterial strain KU011TH with that of the reference strain in the database.

\begin{tabular}{|c|c|c|}
\hline Gene & Identity (\%) & Resistant to \\
\hline acrA & 43.10 & aminoglycosides, beta-lactams and fluoroquinolones \\
\hline & & $\begin{array}{c}\text { panipenem, penems, aztreonam, sulfonamides, azithromycin, novobiocin, } \\
\text { meropenem, colistin, ciprofloxacin }\end{array}$ \\
\hline $\operatorname{acr} B$ & 54.08 & $\begin{array}{c}\text { erythromycin, tetracycline, polymyxin, trimethoprim, aminocoumarin antibiotics, } \\
\text { beta-lactams, fluoroquinolones, chloramphenicol, macrolides and tetracycline } \\
\text { derivatives }\end{array}$ \\
\hline alas & 58.72 & novobiocin and aminocoumarin antibiotics \\
\hline $\operatorname{ampC}$ & 93.99 & cephalosporins and beta-lactams \\
\hline bepE & 97.92 & tetracycline, fluoroquinolones and tetracycline derivatives \\
\hline $\operatorname{mac} B$ & 52.72 & erythromycin and macrolides \\
\hline$m f d$ & 50.61 & $\begin{array}{c}\text { sparfloxacin, norfloxacin, nalidixic acid, gatifloxacin, moxifloxacin, levofloxacin, } \\
\text { ciprofloxacin and fluoroquinolones }\end{array}$ \\
\hline nolG & 30.86 & thiamphenicol and chloramphenicol \\
\hline$s m v A$ & 35.61 & fluoroquinolones \\
\hline tufB & 68.22 & kirromycin and elfamycin \\
\hline
\end{tabular}

Eighteen commercial antibiotics were used to evaluate the antibiotic susceptibility of the bacterial strain KU011TH. The strain was resistant to seven common antibiotics, namely, ampicillin (AMP10), chloramphenicol (C30), cephalothin (KF30), novobiocin (NV5), sulfamethoxazole (SXT25), sulfamethoxazole (RL25) and trimethoprim (W5). The strain was also completely susceptible to ciprofloxacin (CIP5), doxycycline (DO30), enrofloxacin (FNR5), neomycin (N30), oxytetracycline (OT30), polymyxin B (PB300) and tetracycline (TE30). The strain exhibited intermediate susceptibility to only four antibiotics used in this experiment, namely, amoxicillin (AML10), erythromycin (E15), 
spectinomycin (SH25) and cefoperazone (SCF105). The levels of resistance or susceptibility to eighteen antibiotics of the strain varied widely (Figure 5). These findings are the first to provide important information regarding the antibiotic resistance levels of the bacterial strain KU011TH. This step is necessary to provide an indication of the potential use of this bacterium in nonclinical or environmental settings.

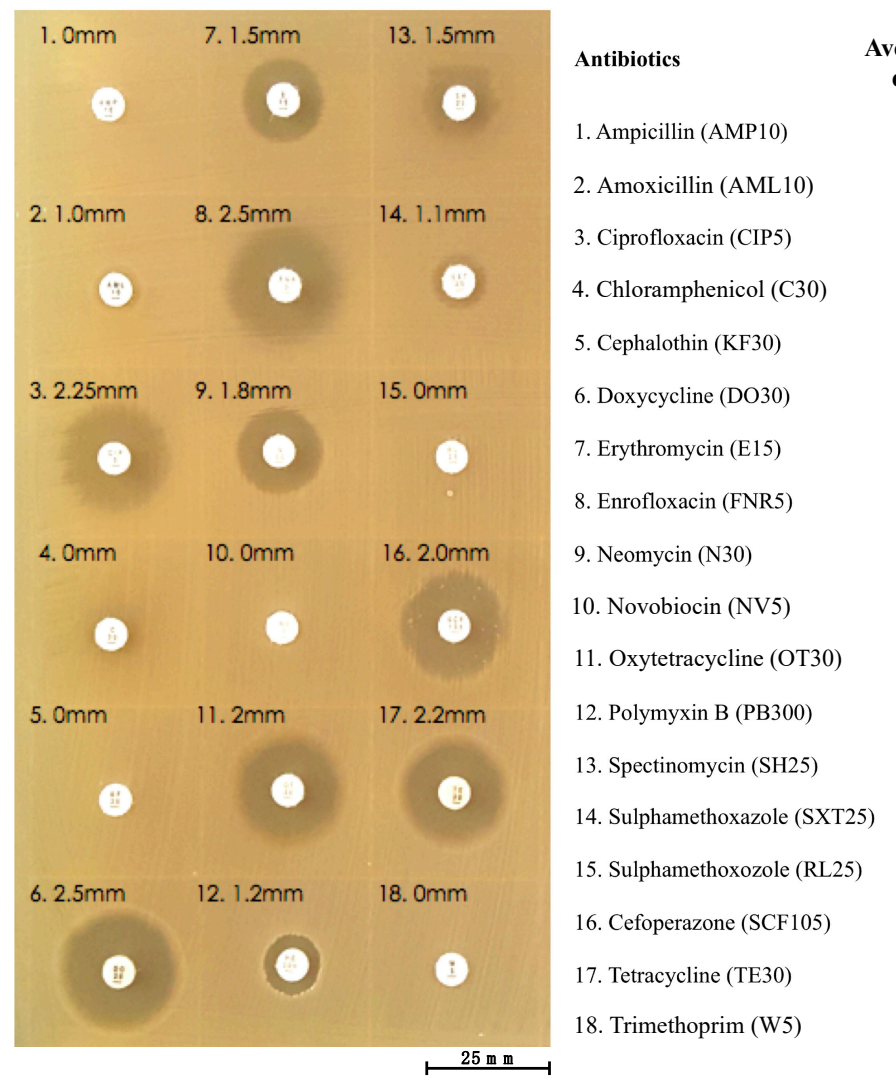

\begin{tabular}{|c|c|}
\hline $\begin{array}{l}\text { Average clear-zone } \\
\text { diameter }(\mathrm{cm})\end{array}$ & $\begin{array}{c}\text { Antimicrobial } \\
\text { susceptibility test }\end{array}$ \\
\hline $0.00 \pm 0.00$ & $\mathrm{R}$ \\
\hline $1.00 \pm 0.05$ & I \\
\hline $2.25 \pm 0.10$ & $\mathrm{~S}$ \\
\hline $0.00 \pm 0.00$ & $\mathrm{R}$ \\
\hline $0.00 \pm 0.00$ & $\mathrm{R}$ \\
\hline $2.50 \pm 0.24$ & S \\
\hline $1.50 \pm 0.13$ & I \\
\hline $2.50 \pm 0.32$ & S \\
\hline $1.80 \pm 0.14$ & $\mathrm{~S}$ \\
\hline $0.00 \pm 0.00$ & $\mathrm{R}$ \\
\hline $2.00 \pm 0.16$ & $\mathrm{~S}$ \\
\hline $1.20 \pm 0.41$ & $\mathrm{~S}$ \\
\hline $1.50 \pm 0.12$ & I \\
\hline $1.10 \pm 0.22$ & $\mathrm{R}$ \\
\hline $0.00 \pm 0.00$ & $\mathrm{R}$ \\
\hline $2.00 \pm 0.18$ & I \\
\hline $2.20 \pm 0.24$ & S \\
\hline $0.00 \pm 0.00$ & $\mathrm{R}$ \\
\hline
\end{tabular}

Figure 5. Antibiotic susceptibility of the bacterial strain KU011TH to eighteen commercial antibiotics.

Because the bacterial strain KU011TH was originally isolated from the skin mucus of healthy bighead catfish, its antagonistic activity against pathogenic bacteria in freshwater and marine aquatic animals was examined to promote and apply the strain as a probiotic for sustainable aquaculture in the future. The strain exhibited strong antagonistic activities against all freshwater fish pathogens, including A. hydrophila, F. columnare, F. roseus, S. agalactiae, S. warneri and E. tarda, in agar dot-spot assays. Interestingly, the strain could also grow in saline conditions and exhibited activity against marine fish pathogens, including V. alginolyticus, V. harveyi, V. parahaemolyticus AHPND and V. vulnificus, in agar dot-spot assays. The levels of antagonistic activity against all pathogenic bacteria in agar dot-spot assays are shown in Table 8 and Figure 6.

To confirm the predominant antagonistic activities of the novel bacterial strain toward various fish pathogens, growth inhibition through interactions between strain KU011TH and pathogens in coculture conditions was further addressed. The inhibitory effects of the bacterial strain KU011TH on pathogen growth were strongly observed in freshwater fish pathogens. In particular, coculture significantly decreased the growth of A. hydrophila $(p<0.05)$, F. columnare $(p<0.01)$, F. roseus $(p<0.01)$, S. agalactiae, S. warneri $(p<0.01)$ and E. tarda $(p<0.01)$ compared to their growth in single cultures (Table 8). Changes in the cell morphology of cocultured bacteria were observed for F. columnare, A. hydrophila and E. tarda, which exhibited fragile cells and accumulation of inactive cells during coculture compared with their single cultures (Figure 6).

In contrast, growth was not significantly decreased in cocultures of the novel probiotic strain KU011TH and marine fish pathogens, including V. alginolyticus, V. harveyi, V. parahaemolyticus AHPND 
and $V$. vulnificus, compared with the corresponding single cultures $(p>0.05)$ (Table 8). Additionally, significantly decreased growth of the bacterial strain KU011TH in coculture with Vibrio spp. compared to the growth in single culture was not observed $(p>0.05)$, whereas significantly decreased growth of the bacterial strain KU011TH in coculture with V. parahaemolyticus AHPND was observed $(p<0.01)$. No changes in the cell morphology of the strain in coculture with Vibrio spp. were observed. Full-scale interactions indicating the antagonistic activity of the bacterial strain KU011TH against various fish pathogens are shown in Table 8 and Figure 6.

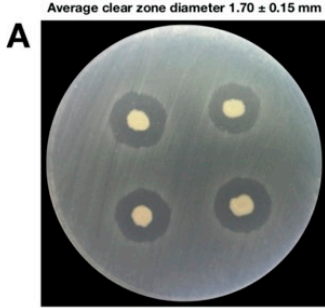

B

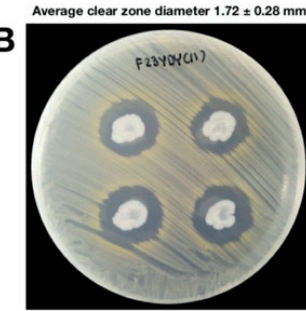

C

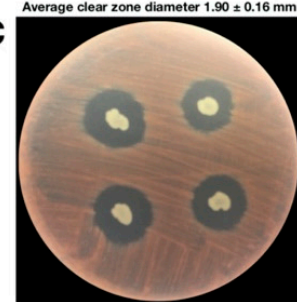

D

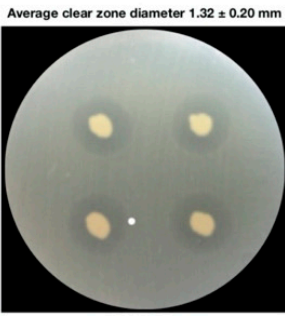

E

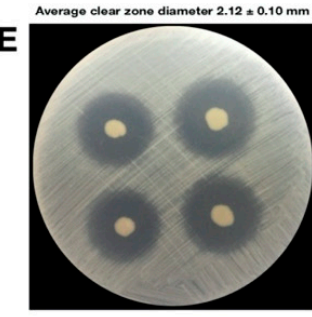

$\mathbf{F}$

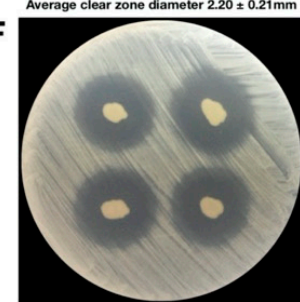

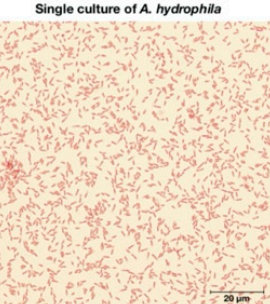
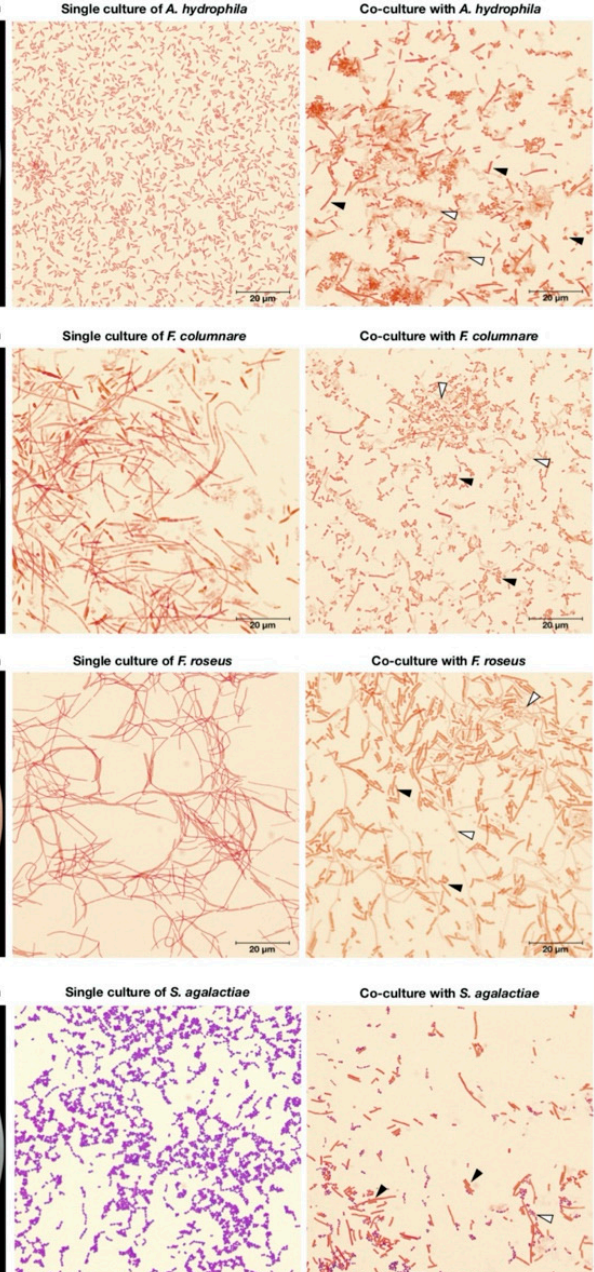

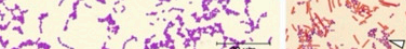

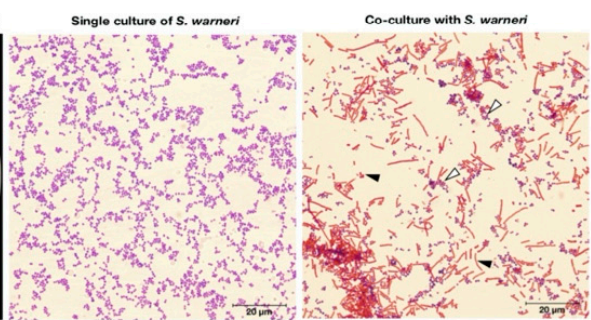

Single culture of $E$ tard

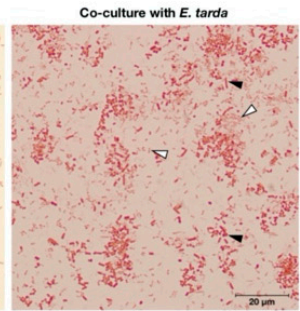

Figure 6. Cont.
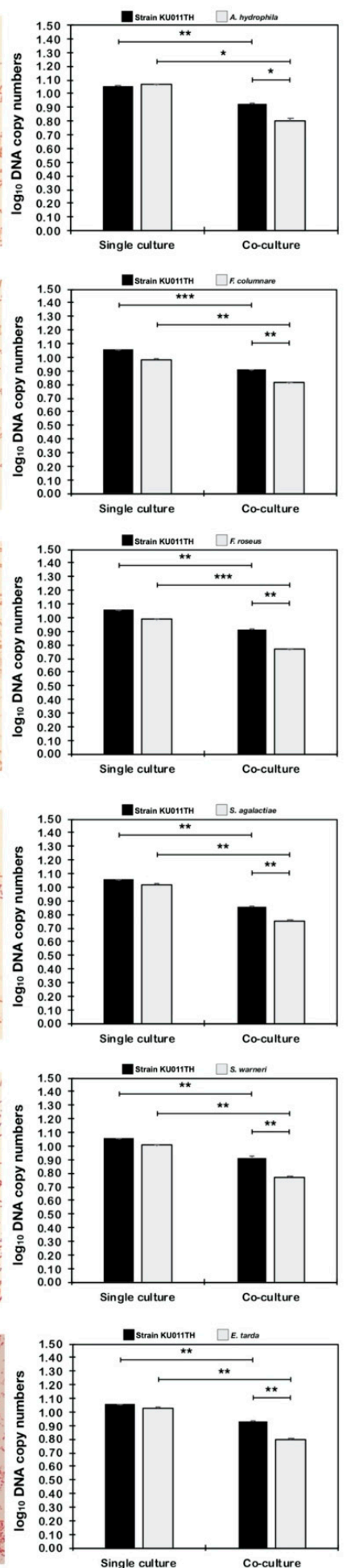

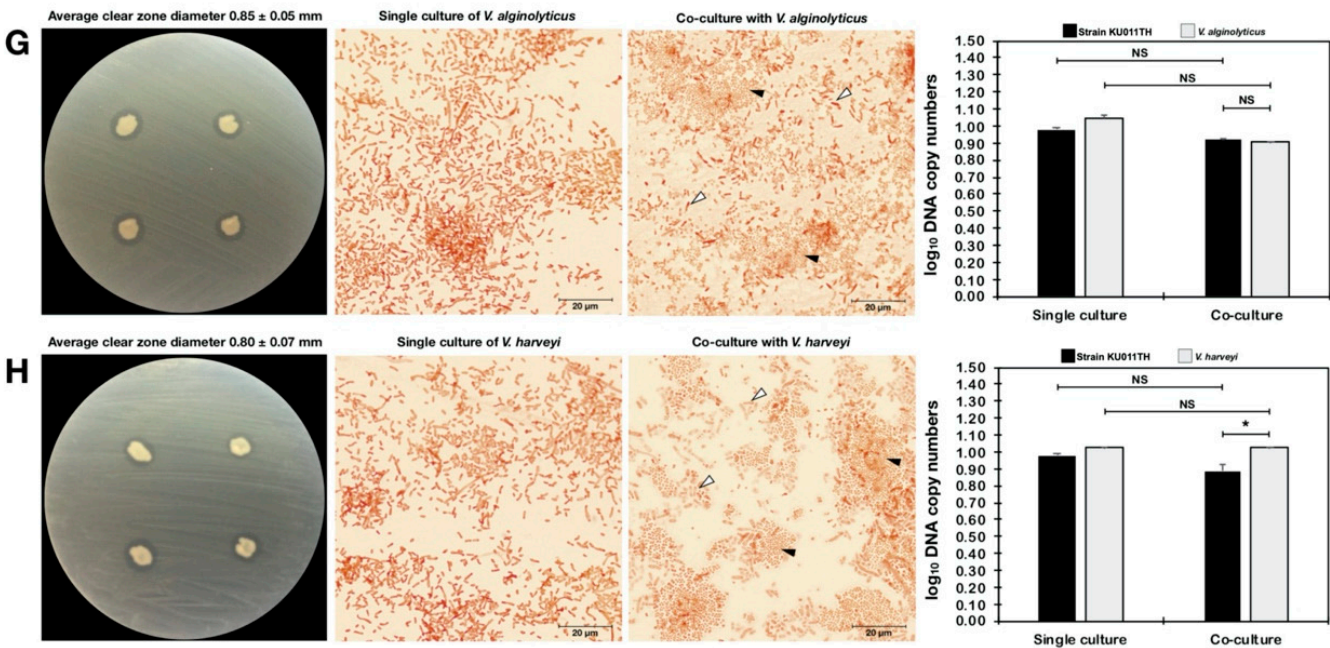

Co-culture with $\mathrm{V}$. haveyi
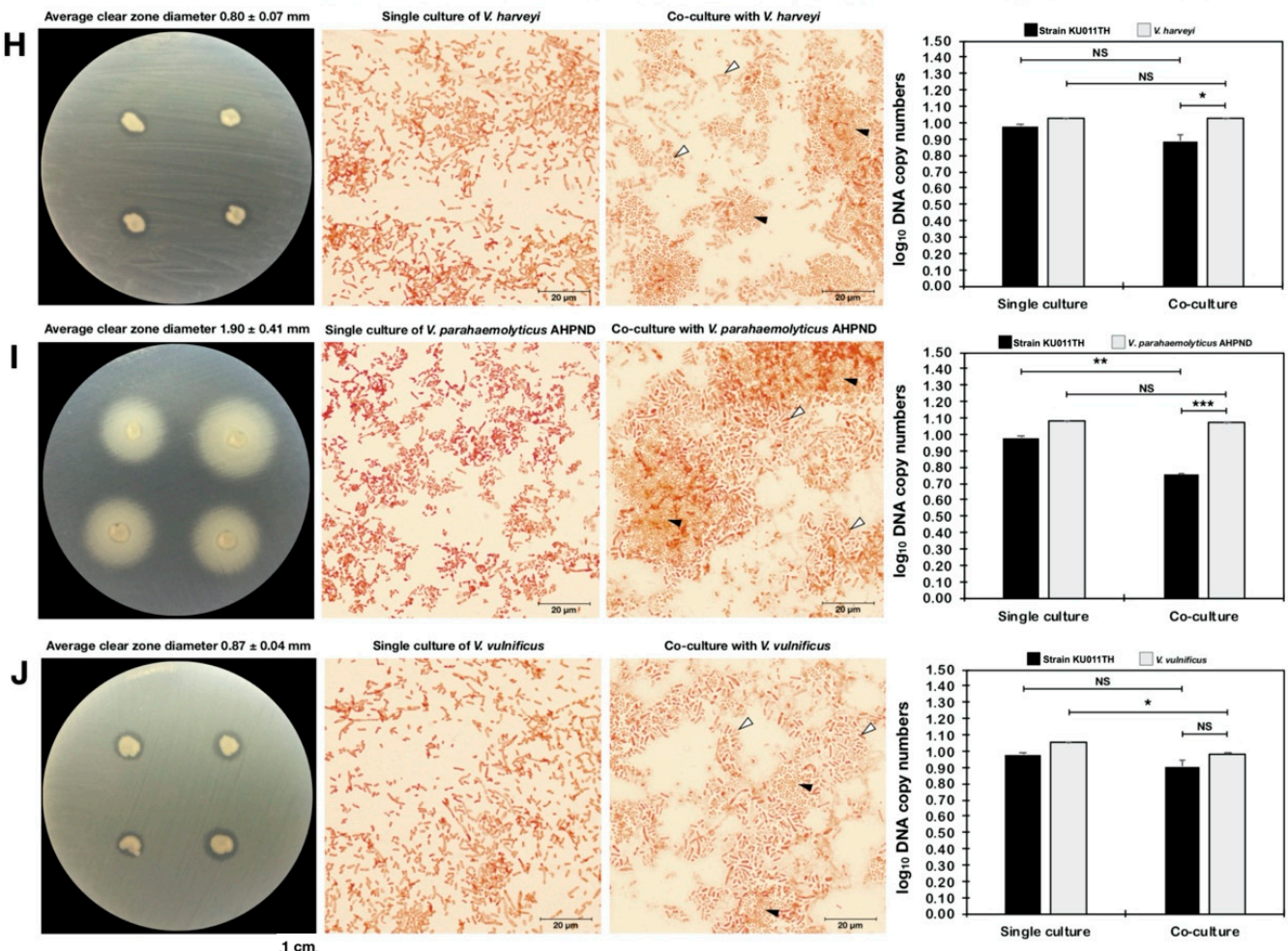

Figure 6. Antagonistic activity of the bacterial strain KU011TH against pathogenic bacteria in freshwater and marine aquatic animals according to agar dot-spot and coculture assays. The results of antagonistic activity are presented as the clear-zone diameters and $\log _{10}$ DNA copy numbers of each strain from agar dot-spot and coculture assays, respectively. Interactions between cocultured bacteria were analyzed using Gram staining by light microscopy $(100 \times)$. The pathogenic bacteria used in the antagonistic activity assay included A. hydrophila (A), F. columnare (B), F. roseus (C), S. agalactiae (D), S. warneri (E), E. tarda (F), V. alginolyticus (G), V. harveyi $(\mathbf{H})$, V. parahaemolyticus AHPND (I) and V. vulnificus (J). Bacterial DNA copy numbers of single culture and cocultures of each strain were quantified by a qPCR assay using specific primers. Superscripts in the coculture results indicate the levels of significant difference compared to the control (single culture) of each strain using Student's $t$-test. For strain $\mathrm{KU} 011 \mathrm{TH}$, the single cultures in NB medium and NB medium with $1.5 \% \mathrm{NaCl}$ were used as the control for cocultures with freshwater or marine fish pathogens, respectively. Black and white arrows indicate the cell morphology of the bacterial strain KU011TH and pathogens during the coculture assay at $24 \mathrm{~h}$, respectively. NS, not significantly different; ${ }^{*}=p<0.05,{ }^{* *}=p<0.01$ and ${ }^{* *}=p<0.001$. 
Table 8. Growth and antagonistic activity against various fish pathogens of the bacterial strain KU011TH.

\begin{tabular}{|c|c|c|c|c|c|}
\hline \multirow{4}{*}{ Bacterial Strain } & \multirow{2}{*}{\multicolumn{2}{|c|}{ Single Culture }} & \multicolumn{3}{|c|}{$\begin{array}{c}\text { Antagonistic Activity of the Bacterial Strain KU011TH } \\
\text { Against Pathogens }\end{array}$} \\
\hline & & & \multicolumn{2}{|c|}{ Coculture Assay } & $\begin{array}{l}\text { Dot-Spot } \\
\text { Assay }\end{array}$ \\
\hline & \multicolumn{2}{|c|}{$\begin{array}{l}\text { DNA Copy Number of Bacterial } \\
\text { Cells (copies/mL) }\end{array}$} & \multicolumn{2}{|c|}{$\begin{array}{l}\text { DNA Copy Number of Bacterial Cells } \\
\text { (copies/mL) }\end{array}$} & \multirow{2}{*}{$\begin{array}{l}\text { Clear-Zone } \\
\text { Diameter (cm) }\end{array}$} \\
\hline & NB Medium & $\begin{array}{l}\text { NB Medium } \\
\text { with } 1.5 \% \mathrm{NaCl}\end{array}$ & Strain KU011TH & Pathogen & \\
\hline Strain KU011TH & $2.37 \pm 8.81 \times 10^{11}$ & $3.51 \pm 2.14 \times 10^{9}$ & - & - & - \\
\hline Aeromonas hydrophila & $5.47 \pm 3.39 \times 10^{11}$ & - & $2.85 \pm 4.23 \times 10^{8 * *}$ & $2.47 \pm 1.54 \times 10^{6^{*}}$ & $1.70 \pm 0.15$ \\
\hline Flavobacterium columnare & $4.62 \pm 6.84 \times 10^{9}$ & - & $1.30 \pm 2.93 \times 10^{8 * * *}$ & $2.97 \pm 5.01 \times 10^{6 * *}$ & $1.72 \pm 0.28$ \\
\hline Flectobacillus roseus & $6.80 \pm 3.23 \times 10^{9}$ & - & $1.72 \pm 1.18 \times 10^{8 * *}$ & $7.00 \pm 9.98 \times 10^{5 * * *}$ & $1.90 \pm 0.16$ \\
\hline Streptococcus agalactiae & $3.39 \pm 5.37 \times 10^{10}$ & - & $1.45 \pm 2.90 \times 10^{8 * *}$ & $4.00 \pm 1.39 \times 10^{5^{* *}}$ & $1.32 \pm 0.20$ \\
\hline Staphylococcus warneri & $1.87 \pm 1.51 \times 10^{9}$ & - & $1.59 \pm 6.98 \times 10^{8 * *}$ & $8.03 \pm 8.64 \times 10^{5^{* *}}$ & $2.12 \pm 0.10$ \\
\hline Edwardsiella tarda & $5.59 \pm 3.20 \times 10^{10}$ & - & $2.80 \pm 6.22 \times 10^{8 * *}$ & $1.91 \pm 5.38 \times 10^{6 * *}$ & $2.20 \pm 0.21$ \\
\hline Vibrio alginolyticus & - & $1.68 \pm 3.72 \times 10^{11}$ & $2.24 \pm 3.81 \times 10^{8 \mathrm{NS}}$ & $4.78 \pm 6.52 \times 10^{8 \mathrm{NS}}$ & $0.85 \pm 0.05$ \\
\hline Vibrio harveyi & - & $3.56 \pm 1.23 \times 10^{10}$ & $8.46 \pm 9.78 \times 10^{7 \mathrm{NS}}$ & $4.74 \pm 7.58 \times 10^{10 \mathrm{NS}}$ & $0.80 \pm 0.07$ \\
\hline $\begin{array}{l}\text { Vibrio parahaemolyticus } \\
\text { AHPND }\end{array}$ & - & $1.25 \pm 9.69 \times 10^{12}$ & $5.51 \pm 5.13 \times 10^{5^{* *}}$ & $6.44 \pm 1.33 \times 10^{11 \mathrm{NS}}$ & $1.90 \pm 0.41$ \\
\hline Vibrio vulnificus & - & $1.72 \pm 8.93 \times 10^{11}$ & $2.10 \pm 2.47 \times 10^{8 \mathrm{NS}}$ & $4.23 \pm 2.31 \times 10^{9^{*}}$ & $0.87 \pm 0.04$ \\
\hline
\end{tabular}

Bacterial DNA copy numbers of single cultures and cocultures for each strain were quantified by a qPCR assay using specific primers. Superscripts in the coculture results indicate the levels of significant differences compared to the control (single culture) for each strain using Student's $t$-test. For strain KU011TH, single cultures in NB medium and NB medium with $1.5 \%(w / v) ~ N a C l$ were used as controls for cocultures with freshwater or marine fish pathogens, respectively. NB medium, standard nutrient broth; NS, not significantly different; ${ }^{*}=p<0.05,{ }^{* *}=p<0.01$ and $* * *=p<0.001$.

In aquaculture systems worldwide, especially in Thailand, disease outbreaks continue to be a major problem for sustainable development of the aquaculture industry. This issue can negatively impact fish health and economic gain. A number of bacterial species in aquatic environments are capable of causing infectious diseases in various species of freshwater and marine aquatic animals. These pathogens include A. hydrophila (aeromonad septicemia), F. roseus, F. columnare (columnaris disease), S. agalactiae (streptococcosis), S. warneri (staphylococcosis), E. tarda (edwardsiellosis), V. alginolyticus (vibriosis), $V$. harveyi (luminescent vibriosis in shrimps), V. parahaemolyticus AHPND (acute hepatopancreatic necrosis disease) and V. vulnificus (vibriosis). Traditionally, the use of various chemicals, such as pesticides, disinfectants, and antibiotics, is extensive in the treatment of diseases in cultured fishes. However, the adverse effects of these chemicals have been a cause for concern for many years because excessive usage of antibiotics and chemicals can lead to the generation of drug-resistant pathogens as well as to food and environmental contamination $[27,53]$.

The use of probiotics has increased dramatically, with applications in fields ranging from human health care to the aquaculture industry. Consequently, the development of probiotics as an alternative strategy to prevent fish diseases has received increasing attention in the fish farming industry. Probiotics are defined as "live microorganisms which have a beneficial effect to the host" by increasing growth performance, improving nutrient digestion, enhancing immune responses and enriching the quality of the aquatic environment [60]. Common probiotics used in the aquaculture industry include Aeromonas, Bacillus, Enterococcus, Enterobacter, Lactobacillus, Lactococcus, Pseudomonas, and Vibrio species [61]. However, microorganisms with probiotic efficiency originating from the genus Acinetobacter have not been reported to date.

Although the mechanisms underlying the antagonism of probiotics against aquatic pathogens have not been well documented, several studies revealed that most probiotics can produce several antimicrobial compounds, which play a key role in the antagonistic activities against pathogens. As an antagonist against pathogenic bacteria, the bacterial strain KU011TH produced clear zones free of pathogens, demonstrating that the secretion of antimicrobial compounds from the bacterial strain KU011TH could inhibit the growth of different freshwater fish pathogens in coculture conditions. In similar results, the supernatant from the culture medium of Bacillus spp. showed strong inhibitory 
effects on S. typhimurium, L. monocytogenes, S. aureus, V. vulnificus, V. harveyi, E. coli and S. aureus [62]. Previous research has also revealed that Bacillus species can produce various antimicrobial compounds, such as bacteriocin, surfactins, iturin, fengycin, bacilysin, subtilin, and sublancin, some of which have been widely used to control microorganisms in the food industry [63,64]. Additionally, lipopeptide N3 and amicoumacin A are produced by B. amyloliquefaciens and B. pumilus and exhibit strong anti-Vibrio activities, disrupting cell membranes and causing cell lysis [65]. Moreover, lactic acid bacteria (LAB) species can produce a number of antimicrobial compounds, such as hydrogen peroxide and bacteriocin-like substances, which have strong inhibitory activities against the pathogens V. metschnikovi, $V$. harveyi and S. aureus, which infect orange-spotted grouper [66]. Recently, several anti-A. salmonicida compounds isolated from B. velezensis V4 belonging to the iturin, macrolactin, and difficidin groups were identified by [67]. These compounds strongly inhibited the growth of $A$. salmonicida in vitro. However, the antimicrobial mechanisms of the bacterial strain KU011TH on freshwater fish pathogens could not be directly explained, suggesting that some antimicrobial peptides produced by the bacterial strain KU011TH are able to either kill pathogens or inhibit their modes of action. Despite the inactivity of the bacterial strain KU011TH against marine fish pathogens in coculture conditions, this strain showed the ability to grow in culture with Vibrio spp. under the same conditions, suggesting that the strain can grow under high-saline conditions but cannot produce antimicrobial compounds and/or antimicrobial molecules and is thus ineffective against pathogens under these conditions. Further work on the purification and identification of the antimicrobial molecules from the bacterial strain KU011TH will help elucidate the mechanism underlying its antimicrobial activity against various fish pathogens.

\section{Conclusions}

Data from phenotypic, phylogenetic, chemotaxonomic and whole-genome sequence analyses strongly support the classification of the bacterial strain KU011TH as a new member in the Acb complex and in the genus Acinetobacter which is closest to A. pittii. Our findings revealed that the new bacterial strain KU011TH has strong antagonistic activity against various fish pathogens and is the first strain suggested as a potential probiotic from the genus Acinetobacter. Thus, the results from the present study strongly suggest that the novel bacterial strain is worth evaluating for further study of its function and efficacy to support disease resistance in the host, bighead catfish (C. macrocephalus). This novel bacterial strain is the first potential probiotic believed to be safe for host and human health that could further replace the use of antibiotics in catfish farming.

Author Contributions: Conceptualization, A.B. and P.S.; methodology, A.B. and P.S.; software, A.B. and P.K.; validation, A.B., P.S. and P.K.; formal analysis, A.B. and P.S.; investigation, A.B. and P.S.; resources, A.B. and P.S.; data curation, A.B. and P.S.; writing-original draft preparation, A.B.; writing-review and editing, A.B. and P.S.; visualization, A.B., U.N.-N. and P.S.; supervision, P.S. and U.N.-N.; project administration, P.S. and U.N.-N.; funding acquisition, U.N.-N.

Funding: This work was financially supported by the Thailand Research Fund (TRF) and the Betagro Science Center, Thailand. This study is part of the project entitled "Genetics and Biotechnology for Improvement of Aquatic Animal Production" (contract no. DPG5980003) awarded to Professor Uthairat Na-Nakorn under the "Distinguished Research Professor 2016 Award."

Acknowledgments: We would also like to thank the Graduate School at Kasetsart University, Thailand, for partial financial support of the student who is the first author of this article.

Conflicts of Interest: The authors declare no conflict of interest. The funders had no role in the design of the study; in the collection, analyses, or interpretation of data; in the writing of the manuscript, or in the decision to publish the results.

\section{References}

1. Brisou, J.; Prevot, A.R. Studies on bacterial taxonomy. X. The revision of species under Acromobacter group. Ann. Institut Pasteur 1954, 86, 722-728.

2. Peleg, A.Y.; Seifert, H.; Paterson, D.L. Acinetobacter baumannii: Emergence of a successful pathogen. Clin. Microbiol. Rev. 2008, 21, 538-582. [CrossRef] [PubMed] 
3. Yang, C.; Guo, Z.B.; Du, Z.M.; Yang, H.Y.; Bi, Y.J.; Wang, G.Q.; Tan, Y.F. Cellular fatty acids as chemical markers for differentiation of Acinetobacter baumannii and Acinetobacter calcoaceticus. Biomed. Environ. Sci. 2012, 25, 711-717. [PubMed]

4. Harding, C.M.; Tracy, E.N.; Carruthers, M.D.; Rather, P.N.; Actis, L.A.; Munson, R.S., Jr. Acinetobacter baumannii strain M2 produces type IV pili which play a role in natural transformation and twitching motility but not surface-associated motility. MBio 2013, 4, e00360. [CrossRef] [PubMed]

5. Bouvet, P.J.; Jeanjean, S. Delineation of new proteolytic genomic species in the genus Acinetobacter. Res. Microbiol. 1989, 140, 291-299. [CrossRef]

6. Bouvet, P.J.M.; Grimont, P.A.D. Taxonomy of the genus Acinetobacter with the recognition of Acinetobacter baumannii sp. nov., Acinetobacter haemolyticus sp. nov., Acinetobacter johnsonii sp. nov., and Acinetobacter junii sp. nov. and emended descriptions of Acinetobacter calcoaceticus and Acinetobacter lwoffii. Int. J. Syst. Evol. Microbiol. 1986, 36, 228-240.

7. Gerner-Smidt, P.; Tjernberg, I.; Ursing, J. Reliability of phenotypic tests for identification of Acinetobacter species. J. Clin. Microbiol. 1991, 29, 277-282. [PubMed]

8. Vaneechoutte, M.; Nemec, A.; Musilek, M.; van der Reijden, T.J.; van den Barselaar, M.; Tjernberg, I.; Calame, W.; Fani, R.; de Baere, T.; Dijkshoorn, L. Description of Acinetobacter venetianus ex Di Cello et al. 1997 sp. nov. Int. J. Syst. Evol. Microbiol. 2009, 59, 1376-1381. [CrossRef] [PubMed]

9. Cosgaya, C.; Mari-Almirall, M.; van Assche, A.; Fernandez-Orth, D.; Mosqueda, N.; Telli, M.; Huys, G.; Higgins, P.G.; Seifert, H.; Lievens, B.; et al. Acinetobacter dijkshoorniae sp. nov., a member of the Acinetobacter calcoaceticus-Acinetobacter baumannii complex mainly recovered from clinical samples in different countries. Int. J. Syst. Evol. Microbiol. 2016, 66, 4105-4111. [PubMed]

10. Nemec, A.; Krizova, L.; Maixnerova, M.; Sedo, O.; Brisse, S.; Higgins, P.G. Acinetobacter seifertii sp. nov., a member of the Acinetobacter calcoaceticus-Acinetobacter baumannii complex isolated from human clinical specimens. Int. J. Syst. Evol. Microbiol. 2015, 65, 934-942. [CrossRef] [PubMed]

11. Maslunka, C.; Gifford, B.; Tucci, J.; Gürtler, V.; Seviour, R.J. Insertions or deletions (Indels) in the rrn 16S-23S rRNA gene internal transcribed spacer region (ITS) compromise the typing and identification of strains within the Acinetobacter calcoaceticus-baumannii (Acb) complex and closely related members. PLoS ONE 2014, 9, e105390. [CrossRef] [PubMed]

12. Chen, T.L.; Lee, Y.T.; Kuo, S.C.; Yang, S.P.; Fung, C.P.; Lee, S.D. Rapid identification of Acinetobacter baumannii, Acinetobacter nosocomialis and Acinetobacter pittii with a multiplex PCR assay. J. Med. Microbiol. 2014, 63, 1154-1159. [CrossRef] [PubMed]

13. Gu, T.; Lu, C.; Chen, H. Acine to bacter baumannii a novel pathogen of acute epidemic in mandarin fish (Siniperca chuatsi). Wei Sheng Wu Xue Tong Bao 1997, 24, 104-106,183.

14. Xia, L.; Xiong, D.; Gu, Z.; Xu, Z.; Chen, C.; Xie, J.; Xu, P. Recovery of Acinetobacter baumannii from diseased channel catfish (Ictalurus punctatus) in China. Aquaculture 2008, 284, 285-288. [CrossRef]

15. Wang, X.; Li, J.; Cao, X.; Wang, W.; Luo, Y. Isolation, identification and characterisation of an emerging fish pathogen, Acinetobacter pittii, from diseased loach (Misgurnus anguillicaudatus) in China. Antonie Leeuwenhoek 2019. [CrossRef] [PubMed]

16. Lu, W.; Chen, H.; Wang, X.; Zou, Y.; Huang, C. Identification and phylogenetic analysis of the pathogenic Acinotobacter baumannii from hybridized prussian carp. Chin. Vet. Sci. 2009, 39, 303-309. [CrossRef]

17. Carr, E.L.; Kampfer, P.; Patel, B.K.; Gurtler, V.; Seviour, R.J. Seven novel species of Acinetobacter isolated from activated sludge. Int. J. Syst. Evol. Microbiol. 2003, 53, 953-963. [CrossRef] [PubMed]

18. Kang, Y.S.; Jung, J.; Jeon, C.O.; Park, W. Acinetobacter oleivorans sp. nov. is capable of adhering to and growing on diesel-oil. J. Microbiol. 2011, 49, 29-34. [CrossRef] [PubMed]

19. Kim, O.S.; Cho, Y.J.; Lee, K.; Yoon, S.H.; Kim, M.; Na, H.; Park, S.C.; Jeon, Y.S.; Lee, J.H.; Yi, H.; et al. Introducing EzTaxon-e: A prokaryotic $16 S$ rRNA gene sequence database with phylotypes that represent uncultured species. Int. J. Syst. Evol. Microbiol. 2012, 62, 716-721. [CrossRef] [PubMed]

20. Krizova, L.; Maixnerova, M.; Sedo, O.; Nemec, A. Acinetobacter bohemicus sp. nov. widespread in natural soil and water ecosystems in the Czech Republic. Syst. Appl. Microbiol. 2014, 37, 467-473. [CrossRef] [PubMed]

21. Krizova, L.; McGinnis, J.; Maixnerova, M.; Nemec, M.; Poirel, L.; Mingle, L.; Sedo, O.; Wolfgang, W.; Nemec, A. Acinetobacter variabilis sp. nov. (formerly DNA group 15 sensu Tjernberg \& Ursing), isolated from humans and animals. Int. J. Syst. Evol. Microbiol. 2015, 65, 857-863. [PubMed] 
22. Li, Y.; Chang, J.; Guo, L.M.; Wang, H.M.; Xie, S.J.; Piao, C.G.; He, W. Description of Acinetobacter populi sp. nov. isolated from symptomatic bark of Populus $\times$ euramericana canker. Int. J. Syst. Evol. Microbiol. 2015, 65, 4461-4468. [CrossRef] [PubMed]

23. Poppel, M.T.; Skiebe, E.; Laue, M.; Bergmann, H.; Ebersberger, I.; Garn, T.; Fruth, A.; Baumgardt, S.; Busse, H.J.; Wilharm, G. Acinetobacter equi sp. nov., isolated from horse faeces. Int. J. Syst. Evol. Microbiol. 2016, 66, 881-888. [CrossRef] [PubMed]

24. Rooney, A.P.; Dunlap, C.A.; Flor-Weiler, L.B. Acinetobacter lactucae sp. nov., isolated from iceberg lettuce (Asteraceae: Lactuca sativa). Int. J. Syst. Evol. Microbiol. 2016, 66, 3566-3572. [CrossRef] [PubMed]

25. Food and Agriculture Organization of the United Nations (FAO). Fishstat Plus; FAO: Rome, Italy, 2017.

26. Na-Nakorn, U.; Kamonrat, W.; Ngamsiri, T. Genetic diversity of walking catfish, Clarias macrocephalus, in Thailand and evidence of genetic introgression from introduced farmed C. gariepinus. Aquaculture 2004, 240, 145-163. [CrossRef]

27. Mohapatra, S.; Chakraborty, T.; Kumar, V.; DeBoeck, G.; Mohanta, K.N. Aquaculture and stress management: A review of probiotic intervention. J. Anim. Physiol. Anim. Nutr. 2013, 97, 405-430. [CrossRef] [PubMed]

28. Hai, N.V. Research findings from the use of probiotics in tilapia aquaculture: A review. Fish Shellfish Immunol. 2015, 45, 592-597. [CrossRef] [PubMed]

29. Kamlage, B. Methods for General and Molecular Bacteriology; 791 Pages, Numerous Figures and Tables; Gerhardt, P., Murray, R.G.E., Wood, W.A., Krieg, N.R., Eds.; American Society for Microbiology: Washington, DC, USA, 1996.

30. Fredriksson, N.J.; Hermansson, M.; Wilen, B.M. The choice of PCR primers has great impact on assessments of bacterial community diversity and dynamics in a wastewater treatment plant. PLoS ONE 2013, 8, e76431. [CrossRef] [PubMed]

31. La Scola, B.; Gundi, V.A.; Khamis, A.; Raoult, D. Sequencing of the rpoB gene and flanking spacers for molecular identification of Acinetobacter species. J. Clin. Microbiol. 2006, 44, 827-832. [CrossRef] [PubMed]

32. Yamamoto, S.; Harayama, S. PCR amplification and direct sequencing of gyrB genes with universal primers and their application to the detection and taxonomic analysis of Pseudomonas putida strains. Appl. Environ. Microbiol. 1995, 61, 1104-1109. [PubMed]

33. Campanella, J.J.; Bitincka, L.; Smalley, J. MatGAT: An application that generates similarity/identity matrices using protein or DNA sequences. BMC Bioinform. 2003, 4, 29. [CrossRef] [PubMed]

34. Thompson, J.D.; Higgins, D.G.; Gibson, T.J. CLUSTAL W: Improving the sensitivity of progressive multiple sequence alignment through sequence weighting, position-specific gap penalties and weight matrix choice. Nucleic Acids Res. 1994, 22, 4673-4680. [CrossRef] [PubMed]

35. Tamura, K.; Peterson, D.; Peterson, N.; Stecher, G.; Nei, M.; Kumar, S. MEGA5: Molecular evolutionary genetics analysis using maximum likelihood, evolutionary distance, and maximum parsimony methods. Mol. Biol. Evol. 2011, 28, 2731-2739. [CrossRef] [PubMed]

36. Nei, M.; Saitou, N. The neighbor-joining method: A new method for reconstructing phylogenetic trees. Mol. Biol. Evol. 1987, 4, 406-425.

37. Coil, D.; Jospin, G.; Darling, A.E. A5-miseq: An updated pipeline to assemble microbial genomes from Illumina MiSeq data. Bioinformatics 2015, 31, 587-589. [CrossRef] [PubMed]

38. Gurevich, A.; Saveliev, V.; Vyahhi, N.; Tesler, G. QUAST: Quality assessment tool for genome assemblies. Bioinformatics 2013, 29, 1072-1075. [CrossRef] [PubMed]

39. Medigue, C.; Calteau, A.; Cruveiller, S.; Gachet, M.; Gautreau, G.; Josso, A.; Lajus, A.; Langlois, J.; Pereira, H.; Planel, R.; et al. MicroScope-An integrated resource for community expertise of gene functions and comparative analysis of microbial genomic and metabolic data. Brief. Bioinform. 2017, 20, 1071-1084. [CrossRef] [PubMed]

40. Richter, M.; Rossello-Mora, R.; Glockner, F.O.; Peplies, J. JSpeciesWS: A web server for prokaryotic species circumscription based on pairwise genome comparison. Bioinformatics 2016, 32, 929-931. [CrossRef] [PubMed]

41. Auch, A.F.; Klenk, H.-P.; Göker, M. Standard operating procedure for calculating genome-to-genome distances based on high-scoring segment pairs. Stand. Genom. Sci. 2010, 2, 142-148. [CrossRef] [PubMed]

42. Meier-Kolthoff, J.P.; Auch, A.F.; Klenk, H.P.; Goker, M. Genome sequence-based species delimitation with confidence intervals and improved distance functions. BMC Bioinform. 2013, 14, 60. [CrossRef] [PubMed] 
43. Richter, M.; Rossello-Mora, R. Shifting the genomic gold standard for the prokaryotic species definition. Proc. Natl. Acad. Sci. USA 2009, 106, 19126-19131. [CrossRef] [PubMed]

44. Meier-Kolthoff, J.P.; Göker, M. TYGS is an automated high-throughput platform for state-of-the-art genome-based taxonomy. Nat. Commun. 2019, 10, 2182. [CrossRef] [PubMed]

45. Kovacs, N. Identification of Pseudomonas pyocyanea by the oxidase reaction. Nature 1956, 178, 703. [CrossRef] [PubMed]

46. Lawrence, R.C.; Fryer, T.F.; Reiter, B. The production and characterization of lipases from a micrococcus and a pseudomonad. J. Gen. Microbiol. 1967, 48, 401-418. [CrossRef] [PubMed]

47. Sasser, M. Identification of Bacteria by Gas Chromatography of Cellular Fatty Acids; MIDI Inc.: Newark, DE, USA, 1990.

48. Whittaker, P.; Fry, F.S.; Curtis, S.K.; Al-Khaldi, S.F.; Mossoba, M.M.; Yurawecz, M.P.; Dunkel, V.C. Use of fatty acid profiles to identify food-borne bacterial pathogens and aerobic endospore-forming bacilli. J. Agric. Food Chem. 2005, 53, 3735-3742. [CrossRef] [PubMed]

49. Jia, B.; Raphenya, A.R.; Alcock, B.; Waglechner, N.; Guo, P.; Tsang, K.K.; Lago, B.A.; Dave, B.M.; Pereira, S.; Sharma, A.N.; et al. CARD 2017: Expansion and model-centric curation of the comprehensive antibiotic resistance database. Nucleic Acids Res. 2017, 45, 566-573. [CrossRef] [PubMed]

50. Camacho, C.; Coulouris, G.; Avagyan, V.; Ma, N.; Papadopoulos, J.; Bealer, K.; Madden, T.L. BLAST+: Architecture and applications. BMC Bioinform. 2009, 10, 421. [CrossRef] [PubMed]

51. Bauer, A.W.; Kirby, W.M.; Sherris, J.C.; Turck, M. Antibiotic susceptibility testing by a standardized single disk method. Am. J. Clin. Pathol. 1966, 45, 493-496. [CrossRef] [PubMed]

52. National Committee for Clinical Laboratory Standards. Performance Standards for Antimicrobial Disk Susceptibility Tests; National Committee for Clinical Laboratory Standards: Villanova, PA, USA, 1997.

53. Koch, A.L. Growth measurement. In Methods for General and Molecular Bacteriology; Gerhardt, P.R., Murray, G.E., Wood, W.A., Krieg, N.R., Eds.; American Society for Microbiology: Washington, DC, USA, 1994; pp. $248-277$.

54. Nemec, A.; Radolfova-Krizova, L.; Maixnerova, M.; Vrestiakova, E.; Jezek, P.; Sedo, O. Taxonomy of haemolytic and/or proteolytic strains of the genus Acinetobacter with the proposal of Acinetobacter courvalinii sp. nov. (genomic species 14 sensu Bouvet \& Jeanjean), Acinetobacter dispersus sp. nov. (genomic species 17), Acinetobacter modestus sp. nov., Acinetobacter proteolyticus sp. nov. and Acinetobacter vivianii sp. nov. Int. J. Syst. Evol. Microbiol. 2016, 66, 1673-1685. [PubMed]

55. Nemec, A.; Krizova, L.; Maixnerova, M.; van der Reijden, T.J.K.; Deschaght, P.; Passet, V.; Vaneechoutte, M.; Brisse, S.; Dijkshoorn, L. Genotypic and phenotypic characterization of the Acinetobacter calcoaceticus-Acinetobacter baumannii complex with the proposal of Acinetobacter pittii sp. nov. (formerly Acinetobacter genomic species 3) and Acinetobacter nosocomialis sp. nov. (formerly Acinetobacter genomic species 13TU). Microbiol. Res. 2011, 162, 393-404.

56. Kim, P.S.; Shin, N.R.; Kim, J.Y.; Yun, J.H.; Hyun, D.W.; Bae, J.W. Acinetobacter apis sp. nov., isolated from the intestinal tract of a honey bee, Apis mellifera. J. Microbiol. 2014, 52, 639-645. [CrossRef] [PubMed]

57. Malhotra, J.; Anand, S.; Jindal, S.; Rajagopal, R.; Lal, R. Acinetobacter indicus sp. nov., isolated from a hexachlorocyclohexane dump site. Int. J. Syst. Evol. Microbiol. 2012, 62, 2883-2890. [CrossRef] [PubMed]

58. Nishimura, Y.; Ino, T.; Iizuka, H. Acinetobacter radioresistens sp. nov. Isolated from cotton and soil. Int. J. Syst. Evol. Microbiol. 1988, 38, 209-211. [CrossRef]

59. Nemec, A.; Dijkshoorn, L.; Cleenwerck, I.; de Baere, T.; Janssens, D.; van der Reijden, T.J.; Jezek, P.; Vaneechoutte, M. Acinetobacter parvus sp. nov., a small-colony-forming species isolated from human clinical specimens. Int. J. Syst. Evol. Microbiol. 2003, 53, 1563-1567. [CrossRef] [PubMed]

60. Geng, X.; Dong, X.H.; Tan, B.P.; Yang, Q.H.; Chi, S.Y.; Liu, H.Y.; Liu, X.Q. Effects of dietary probiotic on the growth performance, non-specific immunity and disease resistance of cobia, Rachycentron canadum. Aquac. Nutr. 2012, 18, 46-55. [CrossRef]

61. Verschuere, L.; Rombaut, G.; Sorgeloos, P.; Verstraete, W. Probiotic bacteria as biological control agents in aquaculture. Microbiol. Mol. Biol. Rev. 2000, 64, 655-671. [CrossRef] [PubMed]

62. Wu, D.X.; Zhao, S.M.; Peng, N.; Xu, C.P.; Wang, J.; Liang, Y.X. Effects of a probiotic (Bacillus subtilis FY99-01) on the bacterial community structure and composition of shrimp (Litopenaeus vannamei, Boone) culture water assessed by denaturing gradient gel electrophoresis and high-throughput sequencing. Aquac. Res. 2016, 47, 857-869. [CrossRef] 
63. Duan, Y.; Zhang, Y.; Dong, H.; Wang, Y.; Zheng, X.; Zhang, J. Effect of dietary Clostridium butyricum on growth, intestine health status and resistance to ammonia stress in Pacific white shrimp Litopenaeus vannamei. Fish Shellfish Immunol. 2017, 65, 25-33. [CrossRef] [PubMed]

64. Xiong, W.; Sun, Y.; Zhang, T.; Ding, X.; Li, Y.; Wang, M.; Zeng, Z. Antibiotics, antibiotic resistance genes, and bacterial community composition in fresh water aquaculture environment in china. Microb. Ecol. 2015, 70, 425-432. [CrossRef] [PubMed]

65. Xu, H.M.; Rong, Y.J.; Zhao, M.X.; Song, B.; Chi, Z.M. Antibacterial activity of the lipopetides produced by Bacillus amyloliquefaciens M1 against multidrug-resistant Vibrio spp. isolated from diseased marine animals. Appl. Microbiol. Biotechnol. 2014, 98, 127-136. [CrossRef] [PubMed]

66. Yang, G.; Tian, X.; Dong, S.; Peng, M.; Wang, D. Effects of dietary Bacillus cereus G19, B. cereus BC-01, and Paracoccus marcusii DB11 supplementation on the growth, immune response, and expression of immune-related genes in coelomocytes and intestine of the sea cucumber (Apostichopus japonicus Selenka). Fish Shellfish Immunol. 2015, 45, 800-807. [CrossRef] [PubMed]

67. Gao, X.; Zhang, M.; Li, X.; Han, Y.; Wu, F.; Liu, Y. The effects of feeding Lactobacillus pentosus on growth, immunity, and disease resistance in Haliotis discus hannai Ino. Fish Shellfish Immunol. 2018, 78, 42-51. [CrossRef] [PubMed]

(C) 2019 by the authors. Licensee MDPI, Basel, Switzerland. This article is an open access article distributed under the terms and conditions of the Creative Commons Attribution (CC BY) license (http://creativecommons.org/licenses/by/4.0/). 